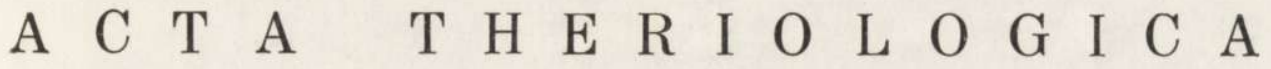

VOL. 18, 14: $247-279$

BIAŁOWIEŻA

August, 1973

Stanisław B O R O W S K I

\section{Variations in Coat and Colour in Representatives of the Genera Sorex L. and Neomys Kaup.}

[With 12 Tables \& 7 Figs.]

\begin{abstract}
Variations in colour of the coat and the course taken by moults were traced in 1123 individuals of Sorex minutus, 115 of S. caecutiens, 1430 of Neomys fodiens and 234 of $N$. anomalus caught in the Białowieża National Park from 1946-1968. The colour of the coat was observed to vary greatly in different species within the same population, showing that care must be taken when using this character as a taxonomic criterion. The ratio of length of fur to body mass is larger in the genus Sorex than in the genus Neomys, as absolute length is greater in the latter. An autumn moult, two spring moults and a senile moult were found to occur in the genus Sorex, while in the genus Neomys there is in addition a juvenile moult. The occurrence of two spring moults in shrews is a phenomenon hitherto unknown in other mammals. Moults are either complete, wave-type or diffusive. The spring wave-type moults are often interrupted. The directions in which moults proceed are similar in all the species considered in this study, as follows: autumn cephalo-ventrad, spring I cephalo-dorsad, spring II caudo-ventrad, senile diffuse, and additionally in the genus Neomys the juvenile moult proceeds ventrad. There is a considerable degree of synchronisation in the time at which moults take place, except that spring moult II is later in Neomys than in Sorex.
\end{abstract}

1. Introduction

2. Material, methods and terminolog

3. Variations in the coat of Neomys fodiens

3.1. Colour of coat

3.2. Length of coat

3.3. Categories, course and time of moults

3.3.1. Juvenile moult

3.3.2. Autumn moult

3.3.3. Spring moult I

3.3.4. Spring moult II

3.3.5. Senile moult

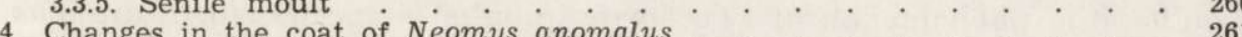

5. Changes in the coat of Sorex minutus. . . . . 263

[247] 
5.1. Colour of coat

5.2. Length of coat

5.3. Categories, course and time of moults

6. Changes in the coat of Sorex caecutiens

7. Moults in captive Soricidae .

8. Discussion

References

Streszczenie

\section{INTRODUCTION}

It might seem that moulting processes in shrews have been relatively thoroughly investigated, judging by the large number of publications dealing with this question. Up until the fifties of the present century the criteria most often used in studies on the moult in Soricidae were differences in length of the hair, without paying much attention to the changes taking place in the skin and consisting, inter alia, in accumulation of pigment. Hamilton (1940, 1944), Findley \& Jones (1956), Williams (1962) state that in Blarina brevicauda the moult proceeds in a transverse direction over the body, or horizontally, reaching this conclusion by observing waves of varying hair length, without referring at all to changes in skin pigmentation. Such waves on light-coloured skin have been identified (B or owski, 1968) as interrupted moults. Other authors, particularly authors of more recent studies, have taken into consideration not only variations in hair length but also in skin pigmentation (B orowski, 1952, 1959, 1963, 1964, 1968; S te i n, 1954; S var c, 1955 ; C r ow cr of t, $1955,1956,1957 ;$ Ni e tha mer, 1956 ; Popov, 1960; Stroganov, 1957; M ichelsen, 1966; I vanter \& Iv a n ter, 1968; Speth, 1969; Ling, 1970). The use of an additional criterion - the direction in which the moult proceeds - has recently made it possible to show that there are two spring changes in the coat of Sorex araneus, differing as to the direction in which they proceed; (Borowski, 1968). Although some authors have observed differences in the direction taken by the spring moult in the genus Sorex (Dehnel, 1949) and the genus Cryptotis (Choat e, 1970), they treated them only as lack of regularity in the moulting process.

The fact that the coat in $S$. araneus changes twice in spring-an unusual phenomenon, not known in other species - induced the author to undertake the most thorough examination possible of changes in coat, particularly in spring, in several other species of shrews of the genera Sorex L. and Neomys Ka u p. The question arises as to the whether the phenomenon of two spring moults is specific to $S$. araneus, or whether it applies to other represnetatives of Soricidae. 


\section{MATERIAL, METHODS AND TERMINOLOGY}

A total of 1430 skins and stuffed skins of Neomys fodiens fodiens (P e n n a t, 1771), 234 of Neomys anomalus milleri (Mottaz, 1907), 1123 of Sorex minutus minutus Lin na e us, 1766 and 115 of Sorex caecutiens karpinski De hne 1, 1949 were used for observations of changes in the coat.

Observations were made on animals which had lived over a month under laboratory conditions. During the period from 1963-1970 moult was observed in 118 individuals of $N$. fodiens, 3 of $N$. a. milleri, and in 8 of $S$. minutus out of from among 232 individuals of $N$. fodiens, 23 of $N$. a. milleri and 54 of $S$. minutus. The whole of the material used for the studies was collected in the Białowieża National Park from 1946-1968.

The material listed above was used for decriptions of coat colour, using Ostwald's tables (1939), but accepting Ridgway's nomenclature as set out by $\mathrm{Z}$ i m merma n $\mathrm{n}$ (1952).

Hairs for measurement of length were taken from the dorsal part of the coat between the scapulae. Each hair was measured to $0.1 \mathrm{~mm}$ from the skin to distal tip.

Up to the present there has been a lack of uniform nomenclature for moulting processes and different authors have used various criteria in relation to different groups of mammals. Those most often employed are age and time of the animal's capture, topography of the moult, and less often - the direction in which the moult proceeds or morphological differentiation of hairs of successive generations. It would appear that Soricidae form convenient material for tracing moult processes, since it is possible to distinguish different types of hair in these animals. Consequently seasonal variations in the coat of shrews and water-shrews have been studied by considerating the type of hair and the character and direction in which the moult proceeds. Determination of the hair length and the number of segments per hair allowed the following types of hairs to be distinguished (cf. B or ow ski, 1952, 1968); (1) summer hair (S) with four segments and sometiems with a short tip (fifth short segment); (2) spring hair (Sp.) with five segments and occasionally a sixth segment (about $5 \%$ of the hairs); and, (3) winter hair $(W$.$) - six-segment hair, sometimes with an additional seventh tip-segment.$

If in addition we apply a time criterion it becomes possible to more exactly classify the summer hair which, may occur in young animals both before and after the juvenile moult as well as in overwintered individuals. Therefore it is possible to distinguish the following: (a) summer hair in young animals before the juvenile moult ( $S$. juv.), (b) final summer hair in young individuals, after the juvenile moult ( $S$. juv. def.); and (c) summer hair in overwintered individuals ( $S$. ad.). When the age of the animals is taken into consideration it is possible to distinguish both young animals and old adults, with first and second winter hair respectively.

Previous studies (B orowski, 1968) distinguished three types of moult: (1) complete moult, which includes the greater part of the whole skin of an animal, (2) wave type moult, which takes place only within a narrow band of skin, $1-5 \mathrm{~mm}$ wide, and which may frequently be interrupted, and (3) senile moult, irregular and rarely taking place on large areas of skin. This moult also is frequently interrupted. When two types of coat occurred in different parts of the body of one individual, e.g. spring and summer on light-coloured skin, then was defined as interrupted moult. 


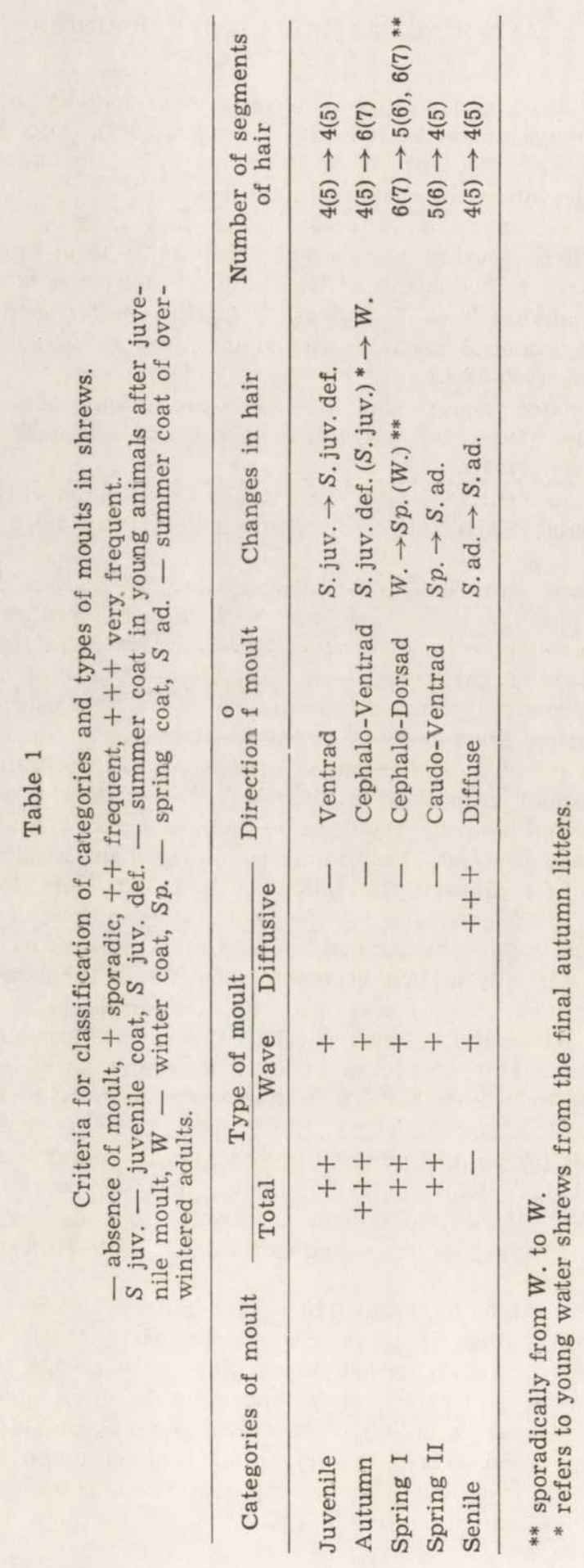


Five directions in which moult took place were distinguished, using terminology almost exactly in accordance with that proposed by Ling (1970).

On the basis of the above criteria the following sequence of categories of moult were established: (1) juvenile moult, (2) autumn moult, (3) spring moult I, (4) spring moult II, (5) senile moult. The criteria and description of these moults are given in Table 1.

\section{VARIATIONS IN THE COAT OF NEOMYS FODIENS}

\subsection{Colour of Coat}

The coat on the back and sides of $N$. fodiens is of a uniform colour. There is little variation in colour of the back and sides, from brown (Chaetura Black, $p n$ 3) to almost black (Bone Brown, $p n$ 6). Usually the lighter colours (Chaetura Black, pn 3 and Clove Brown, $p n$ 4) are typical of young animals with juvenile and summer coats, while the darker colours (Dark Olive, pn 5 and Bone Brown, pn 6) were observed in old adults with summer coats and young animals with winter coats. It is exceptional that the coat of a young individuals is slightly darker (Dark Olive, pn 5), and individuals with lighter-coloured coats are only sporadically encountered among old adults (Clove Brown, pn 4).

The degree of lustre of the coat was also found to vary. While it is difficult to classify the shininess of hairs in a single individual, it is relatively easy to make this kind of analysis when comparing a large number of individuals. A dull, matt coat, or one with a very faint shine, is found in the youngest individuals before the juvenile moult, and the fur of these animals is distinguished by considerable fluffiness. The summer coat of water shrews after the juvenile moult is more shiny and slightly stiffer. The winter coat is distinguished by a decided shine, far greater than that of the spring coat of overwintered individuals (after Spring moult I). The shinest are the summer coats of old adults after spring moult II, and the hair of the latter is the shortest and stiffest.

The ventral side of the water shrew varies greatly in colour, and includes up to 12 shades, from silvery (Marguerite Yellow, $c a$ 1) to dark brown (Clove Brown, pn 4). The most frequent colour in the whole material is the shade termed Pinkish Cinnamon ( $g a$ 3), found in $30 \%$ of the individuals. The percentage of Cream Color (ea 2) and Olive Buff (ec 2) is slightly smaller, $13 \%$ and $12 \%$ respectively, while an even smaller percentage of individuals are Grey (c), 9\%, Olive Buff (ec 1) and Greyish Olive (ig 2), both $8 \%$. The colours Light Buff (ca 2), Cinnamon (ic 3), Deep Olive Buff ( $g$ e 2) and Bister ( $p l$ 4) are represented 
in $4-5 \%$ of individuals. The extreme colours Marguerite Yellow (ca 1) and Clove Born ( $p n$ 4) each form only $1 \%$ (Table 2).

$68 \%$ of the individuals have even colour over the ventral side. The remaining $32 \%$ of water shrews have even coloured over the belly, with

Table 2

Percentages of colours and kinds of fur on the belly and keel of the tail in $N$. fodiens.

\begin{tabular}{|c|c|c|c|c|c|}
\hline \multicolumn{2}{|l|}{ Colour } & \multirow{2}{*}{$\underset{\text { hair }}{\text { Summer }}$} & \multirow{2}{*}{$\begin{array}{l}\text { Winter } \\
\text { hair }\end{array}$} & \multirow{2}{*}{$\begin{array}{l}\text { Spring } \\
\text { hair }\end{array}$} & \multirow{2}{*}{ All } \\
\hline Ridgway & Ostwald & & & & \\
\hline Total & $\begin{array}{l}\stackrel{o}{o} \\
\mathrm{~N}^{*}\end{array}$ & $\begin{array}{r}1074 \\
100 \\
\end{array}$ & $\begin{array}{l}268 \\
100 \\
\end{array}$ & $\begin{array}{r}88 \\
100 \\
\end{array}$ & $\begin{array}{r}1430 \\
100 \\
\end{array}$ \\
\hline \multicolumn{6}{|c|}{ BELLY } \\
\hline $\begin{array}{l}\text { Marguerite Yellow } \\
\text { Light Buff } \\
\text { Olive Buff } \\
\text { Cream Color } \\
\text { Oliwe Buff } \\
\text { Grey } \\
\text { Pinkish Cinnamon } \\
\text { Cinnamon } \\
\text { Deep Olive Buff } \\
\text { Bister } \\
\text { Grayish Olive } \\
\text { Clove Brown }\end{array}$ & $\begin{array}{cc}c a & 1 \\
c a & 2 \\
e c & 1 \\
e a & 2 \\
e c & 2 \\
c & \\
g a & 3 \\
\text { ic } & 3 \\
g e & 2 \\
\text { pl } & 4 \\
\text { ig } & 2 \\
\text { pn } & 4\end{array}$ & $\begin{array}{r}2 \\
2 \\
8 \\
12 \\
12 \\
8 \\
31 \\
6 \\
4 \\
4 \\
9 \\
2\end{array}$ & $\begin{array}{r}- \\
15 \\
5 \\
16 \\
12 \\
10 \\
29 \\
2 \\
3 \\
2 \\
5 \\
1\end{array}$ & $\begin{array}{r}-4 \\
9 \\
13 \\
20 \\
12 \\
22 \\
1 \\
4 \\
2 \\
13 \\
-\end{array}$ & $\begin{array}{r}1 \\
5 \\
8 \\
13 \\
12 \\
8 \\
30 \\
5 \\
4 \\
4 \\
8 \\
1\end{array}$ \\
\hline \multicolumn{6}{|c|}{ KEEL } \\
\hline $\begin{array}{l}\text { White } \\
\text { Whitish } \\
\text { Light brown } \\
\text { Brown } \\
\text { Drak brown (like whole tail) }\end{array}$ & & $\begin{array}{l}12 \\
21 \\
17 \\
40 \\
10\end{array}$ & $\begin{array}{l}32 \\
13 \\
12 \\
23 \\
20\end{array}$ & $\begin{array}{l}24 \\
27 \\
13 \\
17 \\
19\end{array}$ & $\begin{array}{l}18 \\
18 \\
15 \\
34 \\
12\end{array}$ \\
\hline
\end{tabular}

Kind of colour of ventral side

$\begin{array}{lrrrr}\text { Even } & 68 & 68 & 62 & 68 \\ \text { With stripe on belly and patch under throat } & 13 & 12 & 18 & 13 \\ \text { With stripe on belly only } & 7 & 2 & 8 & 6 \\ \text { With patch under throat only } & 7 & 12 & 7 & 8 \\ \text { Cinnamon-colour under lower jaw } & 4 & 5 & 4 & 4 \\ \text { Beige colour under lower jaw } & 1 & 1 & 1 & 1\end{array}$

* Number of individuals. Three measurements were made on each of them.

darked stripes along the axis of the body, dark patches on the throat, or both these characters. Some individuals have distinctly cinnamon or beige fur below the jaw, while the fur on the remainder of the belly in the water shrew varies in colour (Table 2). No individual was ever 
encountered in the Białowieża Primeval Forest which had a dark stripe on the belly joining the spot on the throat, and dark coloured connection with the dark colour of the sides of the body between the fore legs, as described by $\mathrm{K}$ a h m a n n \& R ös s n e r (1956)

The colour of the fur on the kelly of captive water-shrews usually loses the brownish-cinnamon colour after the moult and is either lighter in colour or a darker grey.

The fur on the upper side of the tail is dark- or black-brown, as it is on the back of the body, but the underside and keel vary in colour. An entirely white keel occurs in $18 \%$ of the individuals. The largest number of water shrews with a white keel $(32 \%)$ are encountered in winter, and also in spring $(24 \%)$. A whitish keel, i.e. white with a light sprinkling of brown, occurs in $21 \%$, and light brown in $15 \%$. A brown keel occurs on average in $34 \%$ of the individuals, but more often in summer $(40 \%)$ than in winter or spring (23 and $17 \%)$. A dark brown keel identical in colour with the fur on the upper side of the tail occurs in $10 \%$ of the water shrews in the summer coat, and in 19 and $20 \%$ in the spring and winter coat (Table 2).

A white tip to the tail is encountered in only $2 \%$ of all the shrews, and roughl as many individuals have white patches of fur immediately behind the eyes.

\subsection{Length of Coat}

In the water-shrew the longest hair occurs on the back, and the shortest on the belly which, in accordance with Cerevitinov's nomenclature (1958), may be considered as belonging to the sacro-dorsal type.

It was established, on the basis of 1462 measurements ${ }^{1}$ of hairs in $N$. fodiens, that the animals have the longest hairs in the winter coat (mean $8.0 \mathrm{~mm}$ ) and that far shorter hairs occur in individuals in the spring coat (mean $6.4 \mathrm{~mm}$ ). The shortest are, of course, the summer hairs. Young individuals born in the given calendar year, whether examined before or after the juvenile moult, have hairs almost exactly as long as those in overwintered adults (respectively 5.4 and $5.3 \mathrm{~mm}$ ) -

Variations in hair length expressed by the coefficient of variation (C.V.) are relatively great, varying within limits of $6.2-10.0 \%$, and are in general of a similar order to those in related species $-S$. minutus and S. araneus (Table 3).

${ }^{1}$ Some measurements of hairs were made for individuals with two kinds of hair on the back (interrupted moult), hence the differences between the number of animals examined (1430) and number of measurements of hairs (1462).

Acta theriol. 17 


\subsection{Categories, Course and Time of Moults}

According to Dehnel (1950) the water shrew in the Białowieża Primeval Forest undergoes three moults during its life: autumn, spring and summer. In an earlier study (B o r ow ski, 1952) it was established that two changes of coat take place in spring in these shrews, but the process of change of hair was not observed, on account of the small amount of material obtained from permanent trapping areas.

The material accumulated distinguishes five successive moults in the water shrew, namely: (1) juvenile, (2) autumn, (3) spring I, (4) spring II, and (5) senile.

Table 3

Variations in hair length in some Soricidae.

\begin{tabular}{|c|c|c|c|c|}
\hline Kind of fur & $\mathrm{N}^{*}$ & Min.-Max & $\bar{x} \pm$ S.D. & C.V. \\
\hline \multicolumn{5}{|c|}{ Neomys fodiens } \\
\hline $\begin{array}{l}\text { Summer, juv. } \\
\text { Summer, ad. } \\
\text { Spring } \\
\text { Winter }\end{array}$ & $\begin{array}{r}726 \\
333 \\
95 \\
308\end{array}$ & $\begin{array}{l}3.6-6.7 \\
4.0-6.8 \\
5.2-7.6 \\
6.9-9.5\end{array}$ & $\begin{array}{l}5.40 \pm 0.33 \\
5.34 \pm 0.58 \\
6.39 \pm 0.48 \\
7.99 \pm 0.55\end{array}$ & $\begin{array}{r}6.19 \\
10.88 \\
7.54 \\
6.88\end{array}$ \\
\hline $\begin{array}{l}\text { Summer, juv. } \\
\text { Summer, ad. } \\
\text { Spring } \\
\text { Winter }\end{array}$ & $\begin{array}{l}87 \\
71 \\
10 \\
31\end{array}$ & $\begin{array}{c}\text { mys anomal } \\
4.0-5.8 \\
4.0-5.4 \\
5.0-6.0 \\
5.4-7.6\end{array}$ & $\begin{array}{l}4.80 \pm 0.38 \\
4.53 \pm 0.33 \\
5.44 \pm 0.14 \\
6.75 \pm 0.45\end{array}$ & $\begin{array}{l}8.02 \\
7.33 \\
2.60 \\
6.62\end{array}$ \\
\hline \multicolumn{5}{|c|}{ Sorex minutus } \\
\hline $\begin{array}{l}\text { Summer, juv. } \\
\text { Summer, ad. } \\
\text { Spring } \\
\text { Winter }\end{array}$ & $\begin{array}{l}51 \\
77 \\
11 \\
68\end{array}$ & $\begin{array}{l}2.5-3.5 \\
2.5-3.7 \\
3.4-4.2 \\
4.5-5.9\end{array}$ & $\begin{array}{l}2.97 \pm 0.32 \\
3.00 \pm 0.29 \\
3.74 \pm 0.22 \\
5.03 \pm 0.30\end{array}$ & $\begin{array}{r}10.84 \\
9.83 \\
5.96 \\
5.98\end{array}$ \\
\hline \multicolumn{5}{|c|}{ Sorex caecutiens } \\
\hline $\begin{array}{l}\text { Summer, juv. } \\
\text { Summer, ad. } \\
\text { Spring }\end{array}$ & $\begin{array}{l}51 \\
10\end{array}$ & $\begin{array}{c}3.0-4.3 \\
2.8-3.9 \\
5.0\end{array}$ & $\begin{array}{l}3.36 \pm 0.31 \\
3.32 \pm 0.35\end{array}$ & $\begin{array}{r}9.17 \\
10.61\end{array}$ \\
\hline Winter & 19 & $5.5-7.2$ & $6.25 \pm 0.54$ & 8.66 \\
\hline
\end{tabular}

* Number of individuals. Three measurements were made on each of them.

\subsubsection{Juvenile moult}

The juvenile moult takes place in the youngest water shrews soon after they leave the nest, and as a result the juvenile hair changes to the definitive summer coat of young adult animals. Individuals of the late autumn generation do not undergo this moult. 


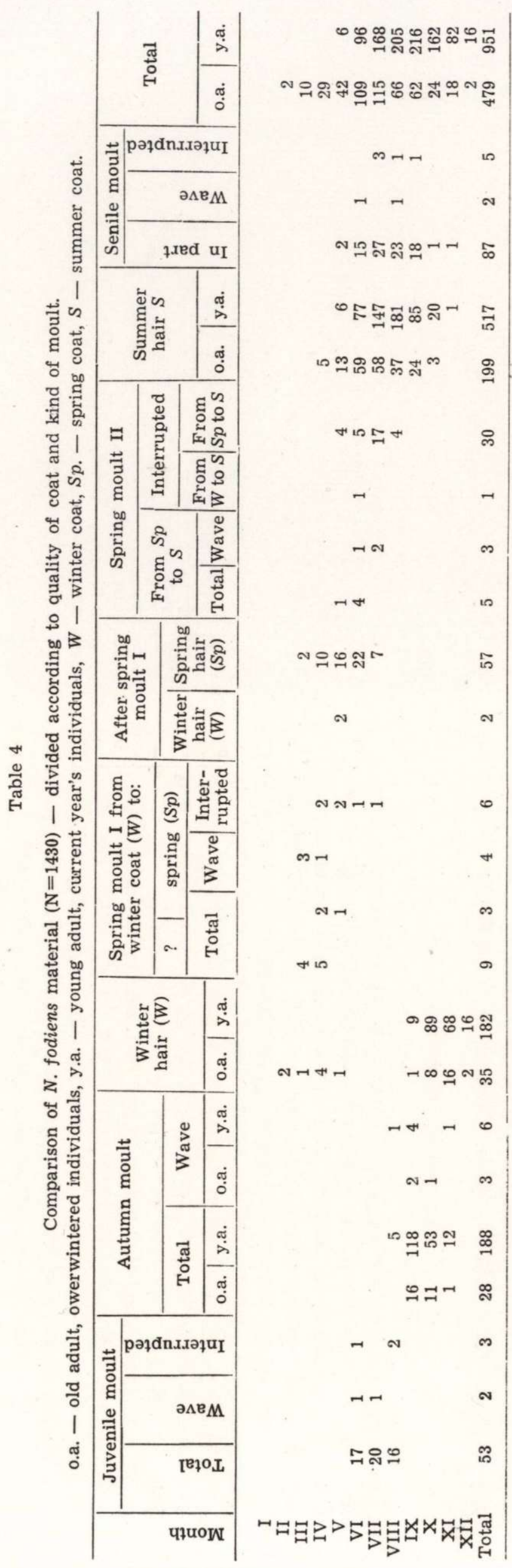


The juvenile moult always begins on the dorsal side of the body, and passes down the sides on to the belly. Changes in coat most often take place in the sacro-lumbar region during the first phase of the moult, then extend cephalad and caudad. After reaching the scapulae the moulting process begins to include the inguinal regions, then moves along the ventral side cephalad and ends on the lower side of the ears and the lower jaw (Fig. 1 A, B, C). The less often moult begins in two patches, in the sacro-lumbar region and the scapular region (Fig. $1 \mathrm{~A}$ ). These patches spread and join and the course taken by the moult from that time onwards is identical to that described above. Exceptionally the juvenile moult begins in the head region and moves along the back caudad, then runs ventrad, and ends at the rear part of the ventral side (Photo 1, Plate IV).

The juvenile moult is often total. Among the 58 moulting shrews (out of 469) $91.4 \%$ of the individuals underwent a total juvenile moult, or moulted over considerable regions of the body. Only occasionally we observed this moult proceed in waves ( 2 individuals) or intervals in moulting ( 3 individuals), Fig. $1 \mathrm{~B}, \mathrm{C}$, Table 4 . The juvenile moult proceeded with decreased in intensity from June to August. In successive months the juvenile moult was observed in $18.7 \%$ of all young shrews in June, $12.5 \%$ in July and $8.8 \%$ in August. The rest had summer coats.

\subsubsection{Autumn moult}

The autumn moult in water shrews consists of a change in the last summer hair of young animals or the summer hair of overwintered adults the winter coat. The moult begins on the back, in the immediate vicinity of the base of the tail (Fig. 2 D, E and Phot. 2, Plate IV) and at first takes in only the dorsal side of the body, proceeding cephalad. When it reaches the scapular region the moult proceeds ventrad into the inguinal regions, then moves cephalad on both the dorsal and the ventral side, finishing, earlier on the upper side of the head than under the throat (Cephalo-Ventrad type).

Out of a total of 225 animals undergoing the autumn moult it was only in 9 animals $(4 \%)$ that wave type moult was observed, the moult being complete in other animals. No interrupted moult was found at all.

Among moulting individuals we found 31 overwintered adults $(32.3 \%$ of all animals from this age group) which had changed from summer to winter coat for undoubtedly the second time in their lives (Table 4). This fact merits particular emphasis as a phenomenon not encountered in other shrews. 


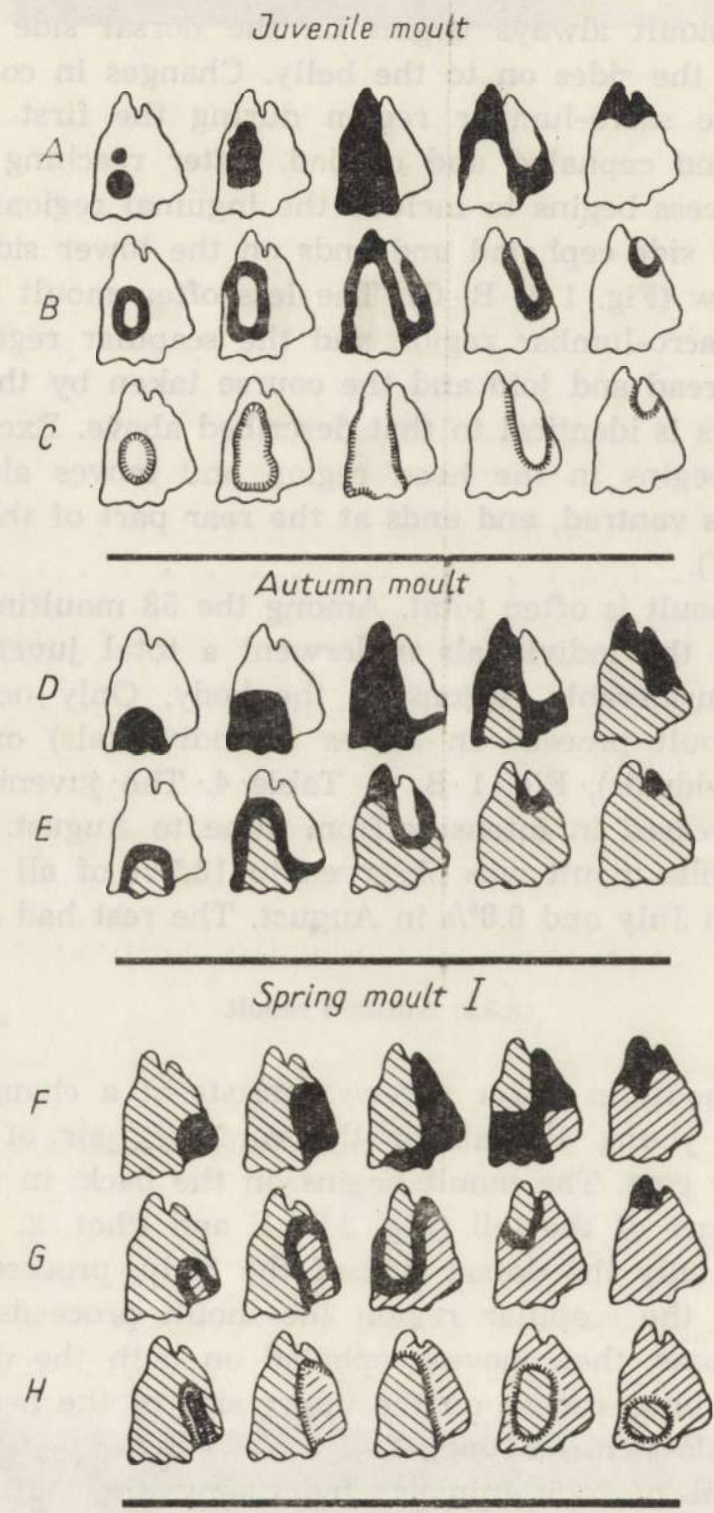

The change from final summer coat to winter begins durig the last 10-day period of August and continues until the final 10-day period of November. The greatest intensity of autumn moult in the population occurs in September and October, when moult was observed respectively in 50 and $35 \%$ of all individuals (Fig. 2,3). 


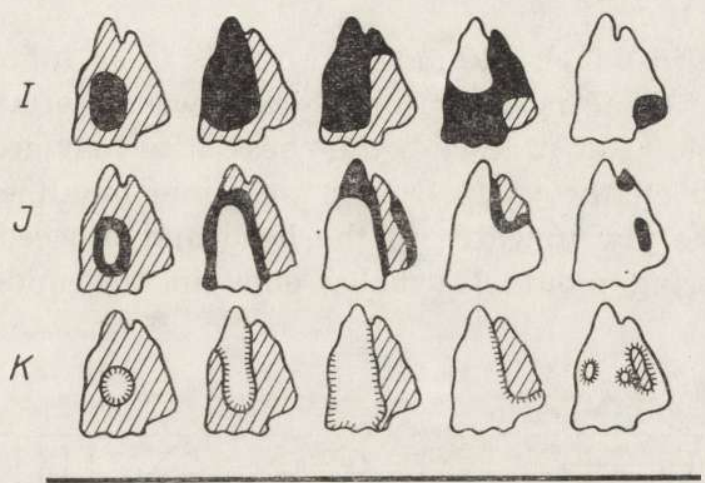

Senile moult

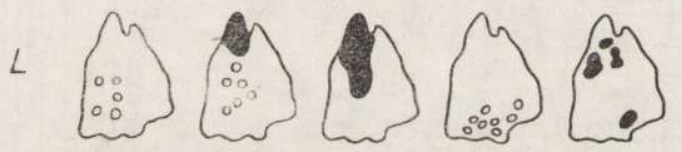

\begin{tabular}{|l|l|l|l|l|}
\hline \multirow{2}{*}{ Skin, A-K } & \multicolumn{4}{|c|}{ Fur } \\
\cline { 3 - 5 } & A,B,C & $D, E$ & $F, G, H$ & $I, J, K$ \\
\hline Light & Summer & Summer & & Summer \\
\hline Light & & Winter & Winter & \\
\hline Dark & Summer & Summer & Winter & Spring \\
\hline VIIIIIIA Light & & & Spring & Spring \\
\hline \multicolumn{5}{|c|}{ Direction of interrupted moult } \\
\hline
\end{tabular}

Fig. 1. Diagram of changes in coat of Neomys fodiens.

$A, D, F, I$ - Total moult, $B, G, E, J$ - Wave-type moult, $C, H, K$ - Interrupted moult, $L-$ Diffuse moult.

The first animals with winter coats appear during the first 10-day period of September, and in October as many as $52 \%$ of all the shrews have long winter hair (Fig. 2). The winter coat persists from November to February inclusive, but individuals with this coat are still encountered up to the first 10 -day period of May $(22 \%)$, Fig. 2.

\subsubsection{Spring moult I}

As the result of spring moult I the $6-7$ segment winter hair changes to spring hair, which is one segment shorter.

'Two water shrews caught in May were classified as animals which had undergone spring moult I, after which their winter coat had grown again (winter coat on thick skin, B or ow s k i, 1968). It would therefore 
appear that the winter hair may occasionally grow again as the result of spring moult $\mathrm{I}$.

The direction in which the moult proceeds is as follows: the inguinal regions are the first to moult, after which new hair grows on the ventral side cephalad and after it reaches the chest, new hair grows in the sacral region and then on the back. During this time moult extends from the region under the jaw upwards to the head and proceeds caudad on the dorsal side. Spring moult I usually ends in the middle of the back (Fig. $1 \mathrm{~F}, \mathrm{G}, \mathrm{H}$ ).

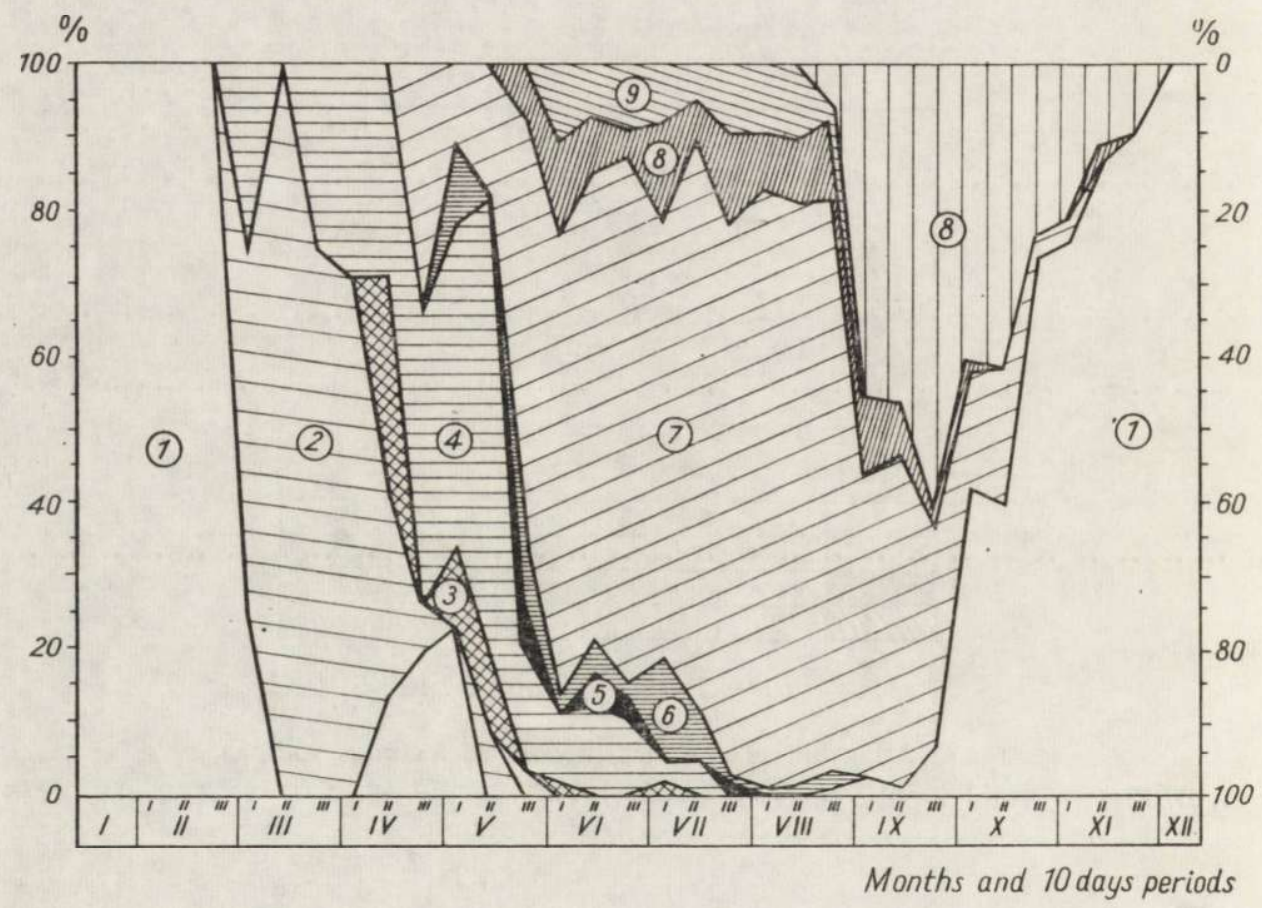

Fig. 2. Successive changes of coat in European Water shrew, $N$. fodiens from 1946$1968(\mathrm{~N}=1430)$, expresed as percentages of individuals in ten-day period samples, classified according to the kind of fur and phase of moulting.

1 - Winter hair, 2 - Spring moult I, 3 - Interval in spring moult, 4 - Spring hair, 5 - Spring moult II, 6 - Interval in spring moult II, 7 - Summer hair, 8 Senile moult, 9 - Juvenile moult, 10 - Autumn moult.

The moult may also proceeds dorsad, first into the area round the head and then extends caudad, ending in the sacral region. In such cases this gives the appearance of the wave of changes in the coat moving caudad and in the form of a ring round the body extending over the sides and back (with the ventral side moulted earlier). The 
course taken by spring moult I is identical in the two sexes, winter coat near the lateral glands in males and mammillae in females often changes in spring before the true moult.

In the study material 16 animals were in process of moulting, 4 out of which were undergoing wave type moult (Fig. $1 \mathrm{G}$, Phot. $3 \mathrm{~A}$, Plate V), 12 - complete moult (Fig. $1 \mathrm{~F}$, Phot. $3 \mathrm{~B}$ ), and a further 6 interrupted moult (Fig. $1 \mathrm{H}$, Table 4).

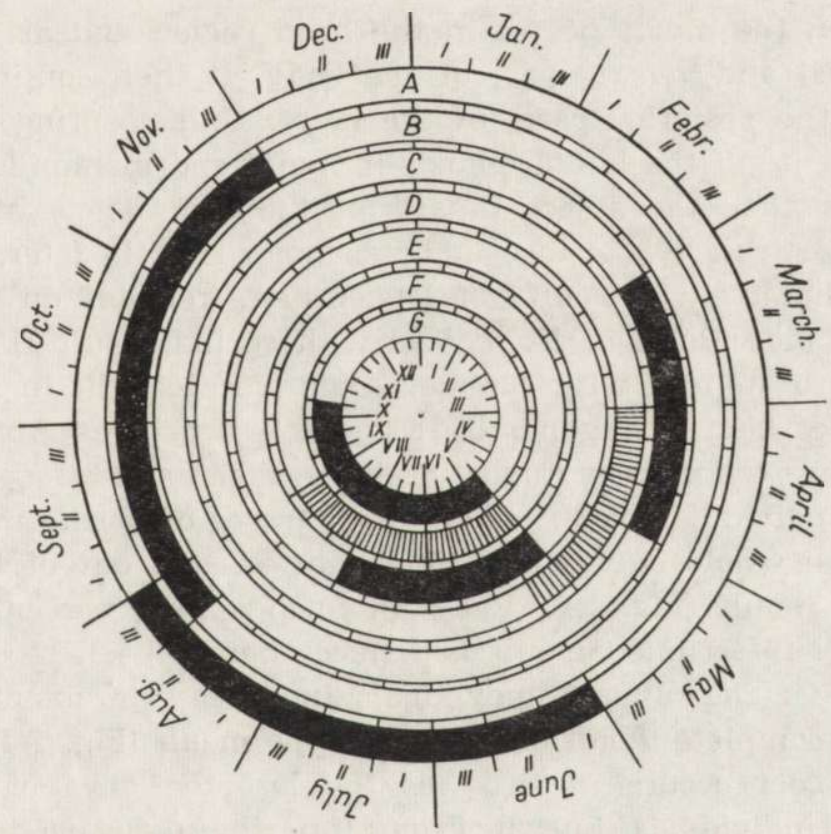

Fig. 3. Times of moult in $N$. fodiens.

A - Juvenile moult, B - Autumn moult, C - Spring moult I, D - Interrupted spring moult I, E - Spring moult II, F - Interrupted spring moult II, G - Senile moult.

Spring moult I invariably began during the first 10-day period of March, and lasted to the end of April in each calendar year in the material studied (Fig. 2 and 3). Only one individual in this moult was found in the second 10-day period of May.

Water shrews with spring coats appear in traps in March $(20 \%)$, their number being greatest in April and May (respectively 32 and $35 \%$ ) and fewer in June and July (respectively 10 and 3\%, Fig. 2, Tab. 4). 


\subsubsection{Spring moult II}

Water shrews undergo spring moult II, during which the coat changes from spring to summer. The course taken by this moult is the reverse to spring moult I. It most often begins in the central parts of the back and extends cephalad and caudad from this place, passing into the ventral side slightly earlier in the head area. Spring moult II usually ends in a narrow band in the central part of the belly into which waves of moult descend from both sides and from the front and back of the body (Fig. $1 \mathrm{~J}, \mathrm{~K})$.

Less often the moult begins in the head region and at once extends to the dorsal and ventral part of the body. It then continues ventrad, ending on the posterior parts of the belly. Unlike spring moult I, the skin on the site of the lateral glands in males and mammillae in females moults later than the adjecent parts of the skin. The coat on the extremities, particularly the fore limbs, changes slightly later, and in such cases the characteristic "cuff « of longer hairs remains on the legs.

The first individuals of $N$. fodiens with spring moult II were caught in May. As 5 animals with summer coats were caught in April it may be considered that spring moult II begins as early as April, and ends during the last ten days of August (Table 4, Fig. 2 and 3).

Only 39 individuals of $N$. fodiens with traces of spring moult II were found in the whole of the material collected, and out of these 31 had interrupted moult (Fig. $1 \mathrm{~K}$, Phot. 4). Such a high percentage of individuals with interrupted moult had never before been recorded in any other case. Of the other 8 individuals in process of moulting, 5 were undergoing complete moult and 3 wave type moult (Fig. 1 I, J, Table 4).

Summer coat occurs as early as the last ten days of April (over $30 \%$ of the individuals, Fig. 2). From June to August 66 to $79 \%$ of all animals have summer coats. The percentage of individuals with summer coats decreases sharply in September and October (39 and 21\%) during the intensification of the autumn moult (Fig. 2).

\subsubsection{Senile moult}

At the end of spring moult II the overwintered adults of $N$. fodiens undergo senile moult, during which the summer coat again changes to summer hair and differs only in that it is stiffer and there is a larger number of long fusiform tips (B or ow ski, 1952). Senile moult never extands over the whole of the animal's skin, usually only over small parts of it, and it takes a very irregular course (Fig. $1 \mathrm{~L}$ ). More rarely it covers larger parts of the body, which makes it similar to a complete 
moult (Photo 5B). It is significant that senile moult of this kind takes place only in July and August.

The first individuals with senile moult were caught in the last ten days of May, and the last during the first ten days of October. The collection includes one individual with senile moult caught during the second 10-day period of November (Table 4).

Among the 94 overwintered adults of $N$. fodiens with senile moult, 87 individuals had partly moulted (this including 13 animals in which the moult had extended to larger parts of the body), 2 had undergone moult similar to the wave type and 5 animals had two types of summer hair without dark pigmentation of the skin (interrupted moult, Table 4).

\section{CHANGES IN THE COAT OF NEOMYS ANOMALUS}

$N$. anomalus is a species far more rarely caught than $N$. fodiens in the Białowieża Primaeval Forest and consequently there were only 234 individuals available.

Table 5

Distribution in percentages of colour of coat in $N$. anomalus $(\mathrm{N}=234)$.

\begin{tabular}{|c|c|c|c|}
\hline \multicolumn{2}{|l|}{ Colour } & \multirow{2}{*}{ Eack } & \multirow{2}{*}{ Belly } \\
\hline Ridgway & Ostwald & & \\
\hline Dark Olive & pn 5 & 89 & \\
\hline Clove Brown & pn 4 & 6 & \\
\hline Bister & $p l 4$ & 5 & \\
\hline Marguerite Yellow & ca 1 & & 8 \\
\hline Cream Color & ea 2 & & 11 \\
\hline Olive Buff & ec 2 & & 1 \\
\hline Pinkish Cinnamon & ga 3 & & 19 \\
\hline Cinnamon & ic 3 & & 22 \\
\hline Yellow Ocher & $n c 3$ & & 1 \\
\hline Grey & $c$ & & 24 \\
\hline Grayish Olive & ig 2 & & 14 \\
\hline
\end{tabular}

The range of variation in colour is given in Table 5 . The fur on the back in overwintered adults is always darker than in young animals. Individuals with winter coats, overwintered adults in summer and a considerable percentage of young animals have an almost black (Dark Olive, $p n$ 5) and slightly speckled back. Some of the old adults with summer coats and part of the young animals are blackish-brown (Clove Brown, pn 4). About $5 \%$ of young animals with summer coats are darkbrown or brown in colour (Bister, $\mathrm{pl} \mathrm{4}$ ), and there is none of the speckled appearance characteristic of overwintered adults or individuals with winter coats. It is probably on this account that young brown $N$. anomalus could at the first glance be mistaken for $S$. araneus. 
The shiniest coat is the summer coat in overwintered adults, and less shiny is the winter coat, while the summer coat in young individuals is almost completely matt.

The colour of the belly, which contrasts with the sides and forms a dividing line along the lower limit of the sides, is not so varied as in $N$. fodiens. The dominating colours are greyish-cinnamon (Pinkish Cinnamon, ga 3 and Cinnamon, ic 3) $(41 \%)$, greyish-beige (Cream Color, ea 2) and grey (Grey, $c$ and Grayish Olive, $l g$ 2), jointly $49 \%$ of the individuals.

Table 6

Comparison of $N$. anomalus material $(\mathrm{N}=234)$, classified according to quality of coat and kind of moult.

o. a. - old adult, owerwintered individuals, y. a. - young adult, current year's individuals,

W - winter coat, $S p$. - spring coat, $S$ - summer coat.

\begin{tabular}{|c|c|c|c|c|c|c|c|c|c|c|c|c|c|c|}
\hline \multirow{3}{*}{ Montr } & \multirow{3}{*}{$\begin{array}{c}\text { Juve- } \\
\text { nile } \\
\text { moul } \\
\text { Total }\end{array}$} & \multirow{2}{*}{\multicolumn{2}{|c|}{$\begin{array}{c}\text { Autumn } \\
\text { Total } \\
\end{array}$}} & \multirow{3}{*}{$\begin{array}{c}\frac{\text { moult }}{\text { Wave }} \\
\text { y.a. }\end{array}$} & \multirow{2}{*}{\multicolumn{2}{|c|}{$\begin{array}{c}\text { Winter } \\
\text { hair }(W) \\
\end{array}$}} & \multirow{3}{*}{ 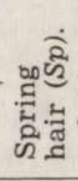 } & \multirow{3}{*}{$\begin{array}{l}\text { Spring } \\
\text { moult } \\
\text { II from } \\
\text { Sp. to S } \\
\text { Total }\end{array}$} & \multirow{2}{*}{\multicolumn{2}{|c|}{$\begin{array}{l}\text { Summer } \\
\text { hair } S\end{array}$}} & \multirow{2}{*}{\multicolumn{2}{|c|}{$\begin{array}{l}\text { Senile } \\
\text { moult }\end{array}$}} & \multicolumn{2}{|c|}{ Total } \\
\hline & & & & & & & & & & & & & \multirow[b]{2}{*}{ o.a. } & \multirow[b]{2}{*}{ y.a. } \\
\hline & & & y.a. & & o.a. & y.a. & & & o.a. & y.a & $\begin{array}{l}\text { In } \\
\text { part }\end{array}$ & $\begin{array}{l}\text { Inter- } \\
\text { rupted }\end{array}$ & & \\
\hline II & & & & & 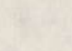 & 1 & & & & & & & & 1 \\
\hline$\underset{\text { III }}{\text { II }}$ & & & & & & & & & & & 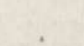 & & & - \\
\hline $\begin{array}{l}\text { III } \\
\text { IV }\end{array}$ & & & & & & & 2 & & 5 & & & & $\begin{array}{l}2 \\
5\end{array}$ & \\
\hline V & & & & & & & 1 & & $\begin{array}{r}5 \\
12\end{array}$ & & 2 & & 15 & \\
\hline VI & & & & & & & 1 & 2 & 19 & 25 & 1 & & 23 & 25 \\
\hline VII & 3 & & & & & & & 2 & 9 & 9 & 6 & & 17 & 12 \\
\hline VIII & 2 & & 4 & & & & & & 7 & 38 & 7 & & 14 & 44 \\
\hline IX & & 2 & 9 & 2 & & & & & 3 & 14 & 6 & 1 & 12 & 25 \\
\hline$x$ & & & 13 & & & 7 & & & & & & & & 20 \\
\hline XI & & & 2 & 1 & 2 & 11 & & & & & & & 2 & 14 \\
\hline XII & & & & & & 3 & & & & & & & & 3 \\
\hline Total & 5 & 2 & 28 & 3 & 2 & 22 & 4 & 4 & 55 & 86 & 22 & 1 & 90 & 144 \\
\hline
\end{tabular}

The tail is usually bicolour, dark brown on the upper side and white or brownish-white on the lower side, with a white keel on the end half of the tail.

The length of the summer coat in young animals is on an average $4.80 \mathrm{~mm}$, and in overwintered animals slightly less $(4.53 \mathrm{~mm})$. The winter and spring coat is far longer (respectively 6.75 and $5.44 \mathrm{~mm}$ ) (Table 3).

The juvenile moult $(n=5)$ begins on the back and runs ventrad and takes place from July to the end of August. The majority of the animals moult completely, and no wave-type and interrupted moults were observed (Table 6). 
Autumn moult was observed in 33 individuals caught during the period from the end of August to the end of November. Only 3 individuals exhibited wave-type moult and the remainder complete moult. Moulting proceeded in a cephalo-ventrad direction. Among individuals changing from summer to winter coat there were also 2 overwintered adults, which suggests that at least some individuals of $N$. anomalus (like $N$. fodiens) prepare to live through a second winter. A total of 24 individuals were found with winter coats.

In the study material there were no animals at all exhibiting spring moult I, but this phenomenon undoubtedly exists since 4 individuals already had spring coats, and change of spring to summer coat (spring moult II) was observed in 4 other individuals. The direction in which this change of coat proceeded is exactly the same as in $N$. fodiens, i.e. Caudo-Ventrad.

There were 141 animals with summer coats in the material, 55 of which were overwintered animals (Table 6). A fairly large group of animals were caught in the senile moult $(n=23), 5$ of which were changing coat over large areas of the body.

\section{CHANGES IN THE COAT OF SOREX MINUTUS}

\subsection{Colour of Coat}

Unlike water shrews, the common shrew is characterized by varied colour on the back, sides and the ventral side of the body. In S. minutus the back is darkest, Chaetura Black ( $p n$ 3) predominating, found in $77 \%$ of the individuals, and Clove Brown ( $p n$ 4) found in $22 \%$. The colour Bister ( $p l 4$ ) occurred in $1 \%$ of the individuals. There are also three shades on the sides of the body, Bister ( $p l$ 4) $81 \%$, Chaetura Black ( $p n$ 3) $10 \%$ and Saccardos Umber ( $p i 3)$ in $9 \%$ of the individuals $(n=77)$. Despite the fact that the same shades occur on the sides of the body, they are lighter in colour than the back and with a different percentage of the colours.

The colour of the ventral side varies from grey (Grayish Olive, $\lg 2$ ), $77 \%$, to light grey (Olive Buff, ec 2) in $3 \%$ of the individuals, and also the following shades: Buffy Brown $(\lg 3) 14 \%$, and Citrine Drab $(\lg 2)$ $6 \%$ of the individuals (Table 7 ).

In young individuals the colour transition between the back and sides, and sides and belly, is always less sharply defined than in overwintered adults.

Changes in degree of shininess of the coat over the animal's life span is exactly the same as in $N$. fodiens. 
Table 7

Distribution in percentages of colour of coat in $S$. minutus $(\mathrm{N}=77)$.

\begin{tabular}{|c|c|c|c|c|}
\hline \multicolumn{2}{|c|}{ Colour } & \multirow{2}{*}{ Back } & \multirow{2}{*}{ Sides } & \multirow{2}{*}{ Belly } \\
\hline Ridgway & Ostwald & & & \\
\hline Clove Brown & pn 4 & 22 & & \\
\hline Chaetura Black & pn 3 & 77 & 10 & \\
\hline Bister & pl 4 & 1 & 81 & \\
\hline Saccardos Umber & pi 3 & 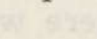 & 9 & \\
\hline Grayish Olive & ig 2 & & & 77 \\
\hline Buffy Brown & $\lg 3$ & & . & 14 \\
\hline Citrine Drab & $\lg 2$ & & & 6 \\
\hline Olive Buff & ec 2 & & & 3 \\
\hline
\end{tabular}

Table 8

Comparison of $S$. minutes material $(\mathrm{N}=1123)$ classified according to quality of coat and kind of moult.

o. a. - old adult, owerwintered individuals, y. a. - young adult, current year's individuals, $W-$ winter coat, $S p$. - spring coat, $S-$ summer coat.

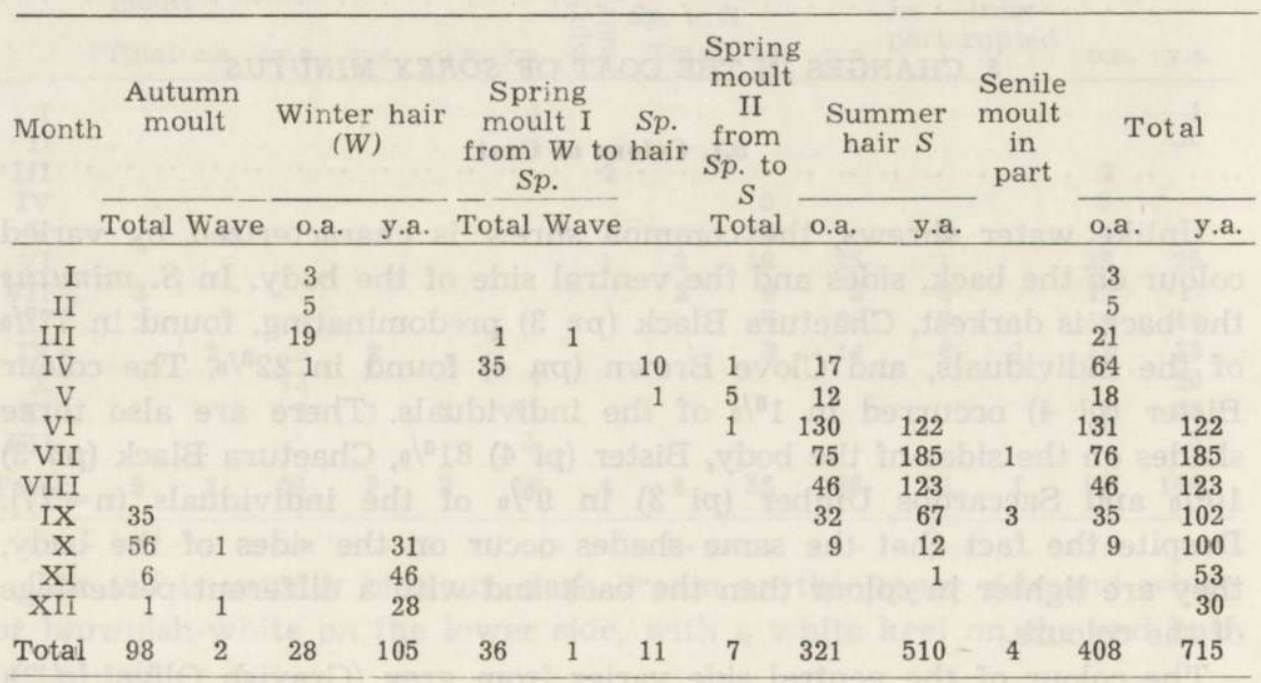

\subsection{Length of Coat}

The length of the different types of coat was defined on the basis of 621 measurements of hairs from 207 individuals. The hair length in the summer coat of young animals and overwintered adults is almost identical (respectively 2.97 and $3.00 \mathrm{~mm}$ ). The mean length of the spring hair is $3.74 \mathrm{~mm}$, and winter $5.03 \mathrm{~mm}$ (Table 3). 


\subsection{Categories, Course and Time of Moults}

The following categories of moults were found in $S$. minutus on the basis of the material examined: autumn, spring I, spring II and senile. As in the case of $S$. araneus (Borow ski, 1968), no juvenile moult was found in $S$. minutus. Although there was a relatively large amount of material (1123 individuals) there are considerable gaps in its continuity (Table 8, Fig. 4).

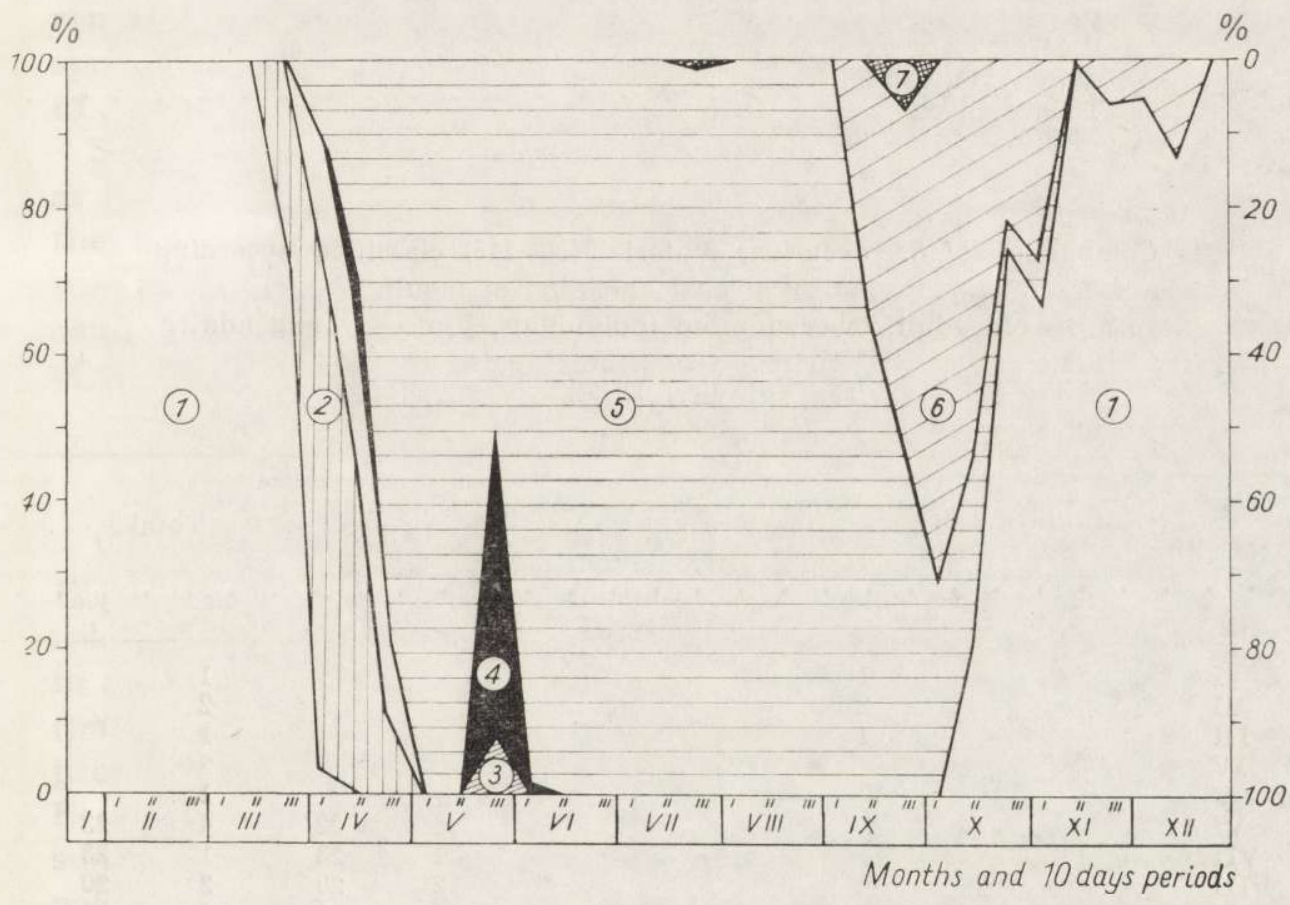

Fig. 4. Successive changes of coat in the Leser shrew, $S$. minutus $(\mathrm{N}=1123$, from 1964-1967), expressed as percentages of individuals in ten-day period samples, classified acording to the kind of fur and phase of moulting.

1 - Winter hair, 2 - Spring moult I, 3 - Spring hair, 4 - Spring moult II, 5 Summer hair, 6 - Autumn moult, 7 - Senile moult.

The course taken by changes in the coat of $S$. minutus agree with that previously described in S. araneus (Borowski, 1968) and in $N$. fodiens, moults take place in $S$. minutus without any disturbances, not a single individual with interrupted moult being found among the 148 moulting animals. Complete moult was most often observed, and only occasionally wave-type moult. 
Table 9

Distribution in percentagens of colour of coat in S. caecutiens $(\mathrm{N}=61)$.

\begin{tabular}{|c|c|c|c|c|}
\hline \multicolumn{2}{|c|}{ Colour } & \multirow{2}{*}{ Back } & \multirow{2}{*}{ Sides } & \multirow{2}{*}{ Belly } \\
\hline Ridgway & Ostwald & & & \\
\hline Bone Brown & $p n 6$ & 3 & & \\
\hline Dark Olive & pn 5 & 3 & & \\
\hline Clove Brown & pn 4 & 5 & & \\
\hline Chaetura Black & pn 3 & 61 & 8 & \\
\hline Bister & pl 4 & 28 & 61 & \\
\hline Brussel Brown & pi 4 & & 31 & \\
\hline Drab & ig 3 & & & 49 \\
\hline Grayish Olive & ig 2 & & & 18 \\
\hline Tawny Olive & le 3 & & & 33 \\
\hline
\end{tabular}

Table 10

Comparison of $S$. caecutiens material $(\mathrm{N}=115)$ classified according to quality of coat and kind of moult.

o. a. - old adult, owerwintered individuals, y. a. - young adult, current year's individuals.

$W$ - winter coat, $S p$. - spring coat, $S$ - sumer coat.

\begin{tabular}{|c|c|c|c|c|c|c|c|c|c|c|}
\hline \multirow{2}{*}{ Month } & \multicolumn{2}{|c|}{ Autumn moult } & \multicolumn{2}{|c|}{$\begin{array}{l}\text { Winter } \\
\text { hair }(W)\end{array}$} & \multirow{2}{*}{$\begin{array}{l}\text { Spring } \\
\text { moult I } \\
\text { from } W \\
\text { to } S p .\end{array}$} & \multirow{2}{*}{$\begin{array}{l}\text { Spring } \\
\text { moult } \\
\text { II from } \\
S p \text { to } S \text {. }\end{array}$} & \multicolumn{2}{|c|}{$\begin{array}{c}\text { Summer } \\
\text { hair } S\end{array}$} & \multicolumn{2}{|c|}{ Total } \\
\hline & Total & Wave & o.a. & y.a. & & & o.a. & y.a. & o.a. & y.a. \\
\hline I & & & 1 & & & & & & 1 & \\
\hline II & & & 2 & & & & & & 2 & \\
\hline III & & & 1 & & & & & & 1 & \\
\hline IV & & & & & $2 *$ & & & & 2 & \\
\hline $\mathrm{V}$ & & & & & & $1^{*}$ & & & 1 & \\
\hline VI & & & & & & & 4 & 23 & 4 & 23 \\
\hline VII & & & & & & & 1 & 23 & 1 & 23 \\
\hline VIII & & & & & & & 2 & 20 & 2 & 20 \\
\hline IX & 4 & & & & & & 1 & 11 & 1 & 15 \\
\hline$x$ & & & & 2 & & & 1 & 4 & 1 & 6 \\
\hline XI & & 1 & & 3 & & & & 1 & & 5 \\
\hline XII & & & & 7 & & & & & & 7 \\
\hline Total & 4 & 1 & 4 & 12 & 2 & 1 & 9 & 82 & 16 & 99 \\
\hline
\end{tabular}

* Interrupted.

The autumn moult begins in $S$. minutus about mid-September, and $97 \%$ of the individuals had completed the moult by the beginning of November. Single moulting individuals were still caught at the end of November. and in December (Fig. 4). During this same period 44 shrews with winter coats were caught. Out of the 100 animals undergoing autumn moult it was only in two cases that wave-type moult was found (Table 8, Photo 6C, Plate VI). 
The spring moult I begins in S. minutus towards the end of March and lasts up to the end of April. Intensification of moulting occurs during the first half of April, when change from winter to spring coat was observed in 34 animals out of 37 . Only one animal underwent wave-type moult, and the remainden - complete moult.

Spring moult II may begin in mid-April (1 individual). From the end of April to mid-May there were no moulting animals in the study material. Among the 15 overwintered adults, 13 already had a summer coat (and must therefore have undergone two spring moults), and the remaining two animals had spring coats. Five old adults undergoing spring moult II were caught at the end of May and one at the beginning of June. No wave-type moult was observed (Table 8).

Senile moult was observed in 4 animals, the first of which was caught at the end of July, and the other three at the end of September. From the beginning of July to mid-September, the period for which there was a gap in our material in respect of senile moult, 69 old adults were, caught which had summer coats without any trace of black pigmentation of the skin (Table 8).

\section{CHANGES IN THE COAT OF SOREX CAECUTIENS}

Variations in the colour of its back in this species are limited in the Białowieża population to five shades, brown being the predominating colour; Chaetura Black ( $p n$ 3) $61 \%$ and Bister ( $p l$ 4) $28 \%$ (Table 9), and in addition Clove Brown ( $p n$ 4) $5 \%$, Dark Olive ( $p n$ 5) and Bone Brown (pn 6) $3 \%$ each. The sides of the body are lighter in colour, since the predominating colour is Bister ( $p l 4)$ in $61 \%$ of individuals, and Brussels Brown ( $p$ i 4) $31 \%$ of individuals (Table 9). Overwintered adults with summer coats and young animals with winter coats are darkest in colour, and it is particularly in these animals that there is a mixture of the darker colours of the sides of the body (Chaetura Black - pn 3).

Variations in the colour of the ventral side of the body is independent of the colour of back and sides. The predominating colour here is Drab (ig 3), $49 \%$, and Tawny Olive (ie 3 ) in $33 \%$ of individuals. Grayish Olive (ig 2 ) is characteristic of only $18 \%$ of the animals (Table 9 ).

The mean length of hair in the summer coat is almost identical in young animals and overwintered adults (respectively 3.36 and $3.32 \mathrm{~mm}$ ). The winter hair is almost twice as long (mean $6.25 \mathrm{~mm}$ ). It proved possible to measure spring hair in one individual only $(5.00 \mathrm{~mm}-$ Table 3). As the amount of material available was somewhat scanty these data should be treated as a guide only. Variation in this character expressed by the coefficient of variation is similar to that in other shrews. 
Only 8 individuals were found in the study material which had traces of moulting, 3 of which exhibited interrupted moult. Autumn moult was found to occur in $S$. caecutiens (5 individuals), also spring moult I (2 individuals with interrupted moult) and spring moult II (1 individual with interrupted moult - Table 10, Photo 7-Plate VI). Senile moult was not, however, observed, but this is undoubtedly due to gaps in our material. It also proved impossible for the same reason accurately to trace the course taken by moults, nevertheless observations of these few individuals established that the course taken by moults in $S$. caecutiens is similar to that in S. araneus (B or ow ski, 1968) and that there are two spring moults in this species also.

Among the five individuals of $S$. caecutiens which were moulting in autumn 4 were caught at the end of September and 1 at the beginning of November. From the middle of October to the end of March all the animals caught had winter coats $(n=16)$. The individuals caught during the course of spring moult I originated from April and one, with interrupted spring moult II, from May. Shrews with summer coats $(n=91)$ were observed from the beginning of June to mid-November (Table 10).

\section{MOULTS IN CAPTIVE SORICIDAE}

Animals brought into the laboratory from field conditions most often died during the first month of life. Maximum survival period was 941 days for $N$. fodiens, 607 days for $N$. anomalus and 261 days for $S$. minutus.

Moults took a different course, and also lasted far longer, in captive animals. The material used for observing moults in captive animals was obtained from summer and autumn, and thus consisted of animals with summer $(S)$ and winter $(W)$ coats. More characteristic cases of moults in three species of Soricidae observed in captive animals are given in diagram form in Fig. 5.

The normal course of moulting, similar to that under natural conditions, was observed in animals with summer coats which were caught from June to July (No. $1-7$ and $14-16-$ Fig. 5 ). The autumn moult began in September in these animals, but even so only in a very small percentage of animals were the direction of changes in coat in completely agreement with that taken by the autumn moult under natural conditions, i.e. Caphalo-Ventrad (e.g. No. 1 in Fig. 5), while the majority of the animals began moulting from both the dorsal and the ventral side (Nos, 2-7). The duration of this moult varied from two weeks (No. 3) to over two months (No. 2 in Fig. 5).

After an interval of $2-3$ months the majority of these animals began spring moult I. The time taken by this moult is far longer and may 


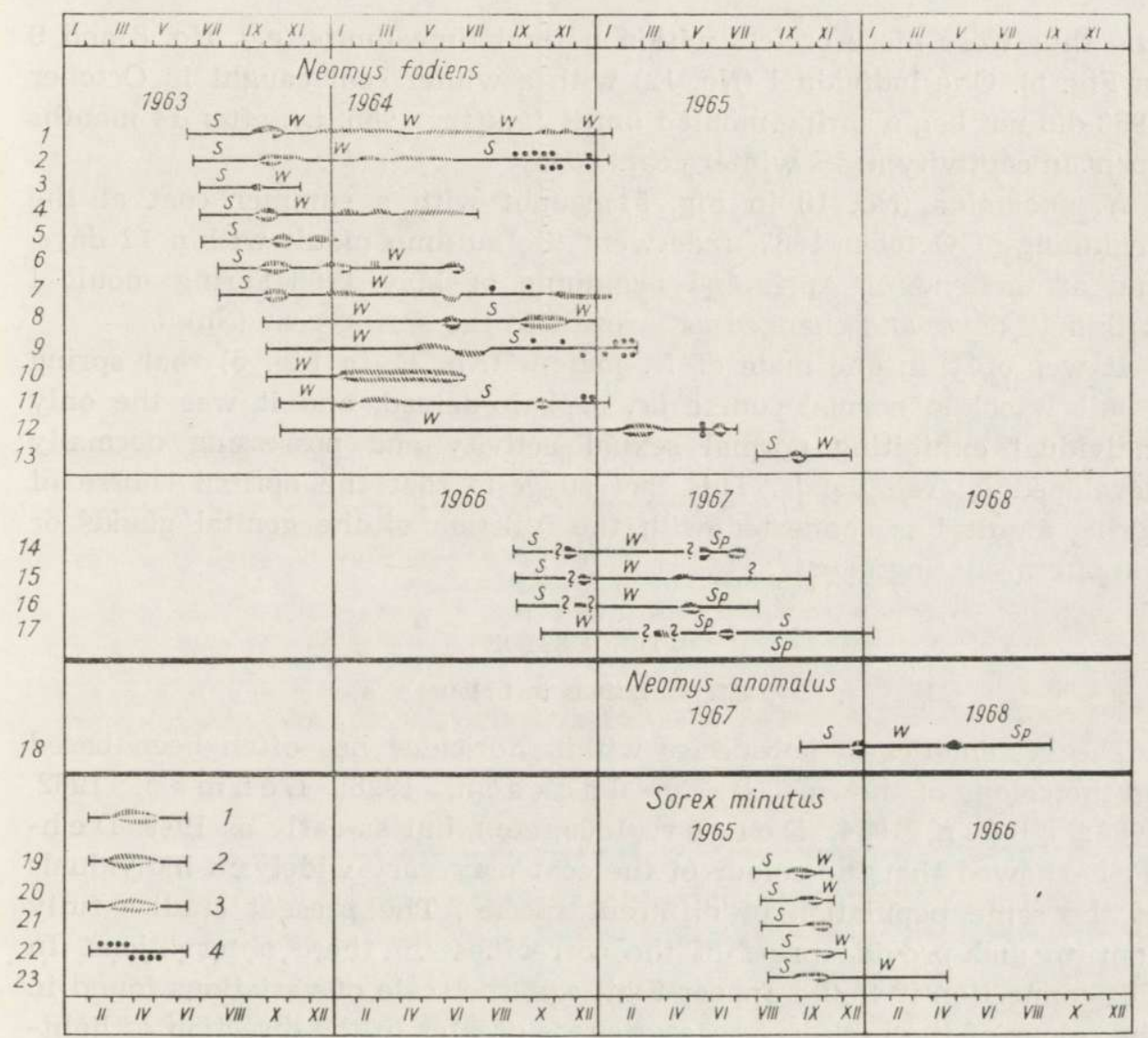

Fig. 5. Changes of coat in captive shrews.

1 - Autumn muult, 2 - Spring moult I, 3 - Spring moult II, 4 - Senile moult. $S$ - Summer hair, $S p$ - Spring hair, $W-$ Winter hair.

even be as much as 5 months (Nos. 1 and 10 in Fig. 5). The animals changed mainly to spring (Nos. 14, 16, 17 on Fig. 5) but also to summer (No. 8, 11) or winter (No. 1 in Fig. 5) coats.

Within a short period of days after spring moult I some of the water shrews began spring moult II (No. 1 and 4), and as a result changed to a summer coat or even back to a winter coat (No. 1 in Fig. 5).

Far greater disturbances in the course of moults were observed in animals caught with winter coats (Nos. 8-12 in Fig. 5). The time at which spring moult I began varied. Some of the individuals began the moult in January, after being kept $2-3$ months in captivity (e.g. Nos 10 and 11), but the majority began during the period from April to June Acta theriol. 18 
and thus were more or less within normal time limits (e.g. No. 8 and 9 in Fig. 5). One individual (No. 12) with a winter coat caught in October 1963 did not begin spring moult I unitil January 1965, i.e. after 14 months spent in captivity in its winter coat.

$N$. anomalus (No. 18 in Fig. 5) caught with a summer coat at the beginning of October 1967 underwent the autumn moult within 12 days, and at the end of April and beginning of May 1968 spring moult I within 12 days, and changed as a result to the spring coat ( $\mathrm{Sp}$ ).

It was only in one male of $N$. fodiens (No. 11 in Fig. 5) that spring moult I took a normal course i.e. cephalo-dorsad, and it was the only individual exhibiting normal sexual activity and possessing normally developed lateral glands. This fact suggests that the normal course of spring moult I is connected with the function of the genital glands or the lateral mating glands.

\section{DISCUSSION}

\subsection{Variations in Colour}

The systematics of subspecies within Soricidae has often been based on the colour of the coat (cf. e.g. J a ck son, 1928; Lehma n, 1962, 1966; J u di n, 1964; D ol gov, 1966, etc.), but as early as 1949 D e h$\mathrm{n}$ el showed that the colour of the coat may vary widely in individuals of the same population of different species. The present studies fully confirm and provide proof of the correctness of these observations. In this connection it would appear that, e.g., the scale of variations found in the colour of the back in S. caecutiens is greater in the direction of lighter colours than in $S$. araneus or S. minutus. Particularly great variation in the colour of the ventral side of the body is observed in $N$. fodiens (cf. Table 2).

The descriptions so far given of differing colour in subspecies and different species of Soricidae mainly represent their geographical variation. The scale of such variation in the colour of the coat in different species, is, however, of the same rank as the variations described within one Białowieża population. Both kinds of intraspecies variation may be greater here, than, for example, in differences between species. This is shown by the relatively small differences in the colour of the coat in two sibling species $-S$. araneus and $S$. gemellus - within the zone of their sympatric occurrence (Ot t \& Ole r t, 1970).

\subsection{Variation in Length of Hair}

The insulating properties of the hair covering in these animals is due to a motionless layer of air confined in the hair, which prevents contact 
between vascularized skin and the external habitat. The thickness of this insulating air layer depends on the structure of the fur, which in Soricidae, is distinct from other mammals, consists of spinous hairs of segmental, fusiform structure with unsegmented conductor hairs scattered among them (Toldt, 1935; Borowski, 1952). The total absence of woolly hair is compensated for some degree by the presence of constrictions between the segments. In addition hair in Soricidae are not very strong ( $\mathrm{Toldt}, 1935 ; \mathrm{Brauckhoff}, 1958$ ) and the structure of the skin itself also exhibits primitive characters (Sokolov, 1968).

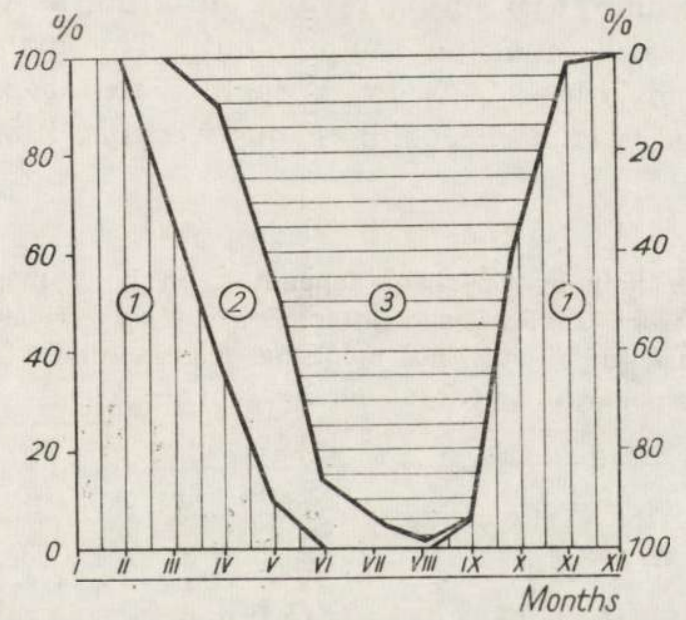

Fig. 6. Percentages of kinds of hair in $N$. fodiens over an annual cycle.

1 - Winter hair, 2 - Spring hair, 3 - Summer hair.

There are three main types of coat (Fig. 6), differing both as to number of segments and length of hair and depending on the season, in the Soricidae examined. The shortest hair always occurs in the summer coat, the medium length hair in the spring coat and the longest hair in the winter coat. It is interesting to note that the summer hair of overwintered adults is generally slightly shorter than that in young animals (Table 3).

In addition there are differences in the length of the various types of hair in the species studied. S. minutus has the shortest hair, while the other species in order of increasing hair length are: S. caecutiens, $S$. araneus, $N$. anomalus and $N$. fodiens (Table 11). It must be emphasised here that the body weights of these animals increase in the same order, but Soricidae, with smaller body dimensions (mass), have relatively longer hair in comparison with their body mass (Table 11) due to their greater energy requirements, since it is known that $S$. minutus or $S$. araneus have a higher metabolic rate than $N$. fodiens $(\mathrm{G} \mathrm{ę} \mathrm{bczy} \mathrm{ń-}$ ska \& Gębczyński, 1965; Gębczyński, 1965, 1971). 


\subsection{Regularities in the Course of Moults in Soricidae}

Among representatives of Soricidae the moulting process has been studied in greatest detail in Sorex araneus (D e h n e 1, 1949; B or owski, 1952, 1959, 1963, 1964, 1968; Stein, 1954; Crow c r of t, 1955, 1957; Švarc, 1955). Exact differentiation between types of hair, the direction in which the moult proceeds, and the age of the animals and their time of capture made it possible to distinguish clearly between the different moults and to describe their sequence. In an earlier study (Borowski, 1968) it was established that there are 4 moults in $S$. araneus: the autumn, two spring moults, differing as to the direction in which they proceed, and the senile moult. The material described above fully confirms these facts for a further two representatives of the genus Sorex and two species of the genus Neomys. It would therefore

Table 11

Changes in length of hair in Soricinae depending on body mass. Average lengths of hair taken from Table 3 and after Borowski (1968). Body weights calculated for 50 young individuals, not moulting, from summer (June-August $-S$ ) and winter (November-February - W).

\begin{tabular}{|c|c|c|c|c|c|c|}
\hline \multirow{2}{*}{ Species } & \multicolumn{2}{|c|}{ Avg. hair length, $\mathrm{mm}(1)$} & \multicolumn{2}{|c|}{ Avg. body wt., g.(2) } & \multicolumn{2}{|c|}{ Ratio $2: 3$} \\
\hline & $S$ & $W$ & $S$ & W & $S$ & W \\
\hline S. minutus & 2.97 & 5.03 & 2.8 & 2.6 & 1.06 & 1.92 \\
\hline S. caecutiens & 3.36 & 6.25 & 4.3 & 3.7 & 0.78 & 1.70 \\
\hline S. araneus & 3.50 & 6.60 & 6.6 & 6.0 & 0.53 & 1.09 \\
\hline N. anomalus & 4.80 & 6.75 & 8.0 & $8.8^{*}$ & 0.60 & 0.77 \\
\hline N. fodiens & 5.40 & 7.99 & 10.5 & 12.3 & 0.51 & 0.65 \\
\hline
\end{tabular}

- average calculated for 26 individuals.

seem that the two-stage change of winter to summer coat, through the transitional stage of the spring hair, as the result of two complete changes of coat, is a widespread phenomenon, at least within Soricidae.

A fifth moult has been shown to take place in representatives of the genus Neomys, the juvenile moult, which does not occur in the genus Sorex, or at least not during the period after leaving the nest. Juvenile moult is a normal phenomenon in many rodents (cf. e.g. Kryltzov, 1964; Ling, 1970). In water shrews born at the beginning of the reproduction season it was observed during the summer months, but in animals born at the end of summer the first change of coat in the life of these water shrews results straight away in the winter coat, as is the case with other mammals ( $\mathrm{Negus,} \mathrm{1958;} \mathrm{Ling,} \mathrm{1970).}$

There are data indicating the significance of the action of somatotropic hormones in moulting processes in young rats ( $\mathrm{M}$ o $\mathrm{h} \mathrm{n}, 1958$ ), and the 
presence of these hormones is also essential in neonatal moults ( $\mathrm{L}$ ing, 1970). There is absolutely no data available on secretion of somatotropin in relation to shrews. The growth of these animals is, however, completed at the time they leave the nest (Dehnel, 1950; Pucek, 1970). There is nothing to show that adult dimensions are attained later in representatives of the genus Neomys than in Sorex, which might suggest that secretion of somatotropic hormones extends in the former genus over the period after leaving the nest. Further physiological studies are undoubtedly necessary in order to elucidate this problem.

There is distinct synchronization of the course taken by moults in all the Soricidae examined, this applys particularly to the start of the moult (Fig. 7) which would appear to indicate that there is some common

\begin{tabular}{|c|c|c|c|c|c|c|c|c|c|c|c|c|}
\hline Species & Moult & , & IIII & $\begin{array}{l}\text { Month } \\
\text { III } \\
\text { iIII }\end{array}$ & 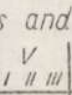 & $\begin{array}{r}10 \mathrm{a} \\
\mathrm{VI} \\
\mathrm{I} \mathrm{II}\end{array}$ & $\begin{array}{l}\text { lays } \\
\mid \text { VII } \\
\text { III III }\end{array}$ & $\begin{array}{l}\text { Deriod. } \\
\mid \begin{array}{lll}\text { VIII } \\
\text { I II III }\end{array}\end{array}$ & \begin{tabular}{|l|l|}
$x$ \\
1
\end{tabular} & $x_{11}^{x}$ & $\left|\begin{array}{c|c|}x 1 & \\
111 & \text { III }\end{array}\right|$ & $\begin{array}{l}x \| \prime \\
\text { XII III } \\
\end{array}$ \\
\hline S. minutus & $\begin{array}{l}A u . \\
\text { Sp. } \\
\text { Sp. } .1 \\
\text { Sen. }\end{array}$ & & & 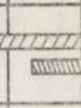 & त्याI & & & & 25 & 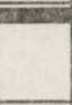 & & \\
\hline S. caecutiens & $\begin{array}{l}\text { Au. } \\
\text { Sp.I } \\
\text { Sp.ll } \\
\text { Sen. }\end{array}$ & & & $202 \pi$ & (1) & & & & & & 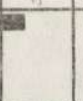 & \\
\hline S.araneus & $\begin{array}{l}A u . \\
\text { sp. I } \\
\text { Sp.ll } \\
\text { sen. }\end{array}$ & & एवता & 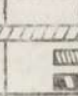 & & & & & & 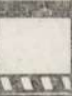 & $6 \times 10$ & \\
\hline N. anomalus & $\begin{array}{l}\text { Juv. } \\
\text { Au. } \\
\text { spi } \\
\text { Sp.l } \\
\text { sen. } \\
\end{array}$ & & & & & & Daming & & J4 & & & \\
\hline N.fodiens & $\begin{array}{l}\text { Juv. } \\
A u . \\
\text { sp. I } \\
\text { s.ll } \\
\text { sen. }\end{array}$ & & & & 8 & II & tion & (2000 & & & & \\
\hline
\end{tabular}

Fig. 7. Periods of moults in some Soricinae.

Kinds of moults indicated as follows: Juv. - Juvenile moult, Au. - Autumn, Sp. I and Sp II - Spring moult I and II, respectively, Sen. - Senile moult.

regulating factor in these processes. It is, however, generally known that seasonal changes in the coats of mammals depend on seasonal changes in the external environmental condition (such as length of day, ambient temperature, of food supply) which affect mammals differently in different years. Hence when analysing longterm material the periods at which moults start and end tend to reflect extreme values.

The autumn moult begins in the middle or at the end of September in the three species studied of the genus Sorex, whereas in representatives of Neomys this takes place at the end of August. The moult lasts in the above animals up to the end of November, and in the case of $S$. minutus even up to December (Fig. 7). The shortening autumn day 
and falling ambient temperature would appear to form a stimulus to the start of this moult.

The spring moult is subject to the strongest influence of the lengthening day in spring. In all species of shrews and water shrews it begins in March, when winter conditions still continue in the Białowieża Primeval Forest often with a thick snow cover. It is possible that this is the reason when under such conditions the coat changes from winter to spring, and not straight away into the summer coat (B o r ow ski, 1968).

Spring moult I ends in Sorex at the end of April, whereas in Neomys it may last up to the beginning of July (Fig. 7). It may be assumed that this delay is conditioned by the far slower warming of the humid biotopes inhabited by water shrews. In addition the spring moult is often interrupted in water shrews (Table 4), which would also appear to show that this moult does not proceed unhindered. It may therefore be assumed that the rhythm of day length determines the time at which the moult starts, while temperature conditions and changes in energy budget regulate the rate at which it takes place.

Table 12

Duration of moult under laboratory conditions.

\begin{tabular}{|c|c|c|c|c|}
\hline \multirow{2}{*}{ Species } & \multirow{2}{*}{$\mathrm{N}$} & \multirow{2}{*}{ Moult - } & \multicolumn{2}{|c|}{ Time of moult, days } \\
\hline & & & Min. - Max. & Avg. \\
\hline \multirow{3}{*}{ S. minutus } & & Autumn & $29-44$ & 37.8 \\
\hline & 5 & Spring I & $5-15$ & 10.6 \\
\hline & 19 & Autumn & $5-45$ & 27.0 \\
\hline \multirow[t]{2}{*}{ S. araneus } & 19 & Spring I & $5-25$ & 13.6 \\
\hline & 5 & Senile & $5-25$ & 15.9 \\
\hline \multirow{3}{*}{ N. anomalus } & & Autumn & 12 & - \\
\hline & 1 & Spring I & 12 & - \\
\hline & 8 & Autumn & $13-76$ & 40.9 \\
\hline \multirow[t]{3}{*}{ N. fodiens } & 1 & Spring I & $23-170$ & 46.2 \\
\hline & 4 & Spring II & $11-98$ & 83.5 \\
\hline & 2 & Senile & $66-120$ & 93.0 \\
\hline
\end{tabular}

The seasonal rhythm of moulting processes is clearly disturbed when animals are kept under laboratory conditions. In individuals which had begun multing soon after being caught, the course taken by the moult was similar to that under natural conditions (Fig. 5). In the majority of cases, however, considerable deviations are observed from the "field normal " primarily considerable extension of the time taken for complete change of coat (in the extreme case of $N$. fodiens no 10 this animal continued to moult for as long as 6 months -- Fig. 5).

Laboratory observations allowed, however, of the tracing the shortest duration of the moult in the Soricidae examined, which undoubtedly points to the maximum physiological capacity of different species in this 
respect. Data given in Table 12 show that shrews can change their coat within 5 days and, in addition, that the moult lasts longer in representatives of the genus Neomys than in the genus Sorex (cf. also Wilcke, 1938; B or ow ski, 1964).

\subsection{Moult and Metabolism}

Up to the present there has been a lack of data on the energy expended during the moult in Soricidae, but it would appear that the organism is involved in considerable expenditure of energy, if the rate, at which complete change of coat can be carried out, is taken into account (cf. Table 12). It would also seem that the costs of the moult results in certain increases in the metabolism of shrews during the yearly cycle.

Comparison of data given by B or ow ski (1968) and Gę bc zyń sk i (1965) indicate that the autumn moult is not correlated with increased metabolism in shrews. The metabolism of the autumn series of shrews was, however, examined in October and at the beginning of November, when the autumn moult has ended. Animals in course of a change of coat were not used for the studies. In addition this moult takes place very swiftly, being either complete or wave type, and never interrupted.

Although winter metabolic level is lower than in summer, it does not differ greatly from the autumn rate. The thermoneutral zone also decreases considerably (cf. G ę b c z y ńs ki, 1965). It would seem that these relatively small changes in the metabolism of shrews during the winter are possible owing to their specific morphological adaptation (G ę b c z y ń s ki, 1965; P u c e k, 1970), since the decrease in shrews body measurements in winter causes contraction of the skin, and consequently the winter coat is $31 \%$ denser than the summer coat (Borowski, 1959) and the insulating properties of longer and denser fur is about $18 \%$ higher (Gębczyński \& Olszewski, 1963). These data apply primarily to $S$. araneus and probably to other representatives of the genus Sorex in which, for instance, the ratio of hair length to body mass (Table 11) is twice as big in winter than in summer. There is no similar data for representatives of the genus Neomys, but the ratio referred to (Table 11) is only about $1 / 3$ larger in winter than in summer. This would point to certain differences between representatives of the two genera, and it may therefore be considered that the mechanisms of physical thermoregulation are relatively well formed in Soricidae, particularly in the smallest representatives of this subfamily, in the genus Sorex.

The spring moults are connected with an intensive increase in the metabolic rate of shrews, but also coincide with the period of rapid increase in body mass and the shrews' start upon the phase of sexual 
activity (Tarkowski, 1957; Pucek, 1959; Gębczyński, 1965; B or ow ski, 1968 and present study). The simultaneous occurrence of all these processes must therefore cause a considerable rise in metabolic rate (G ębczyński, 1965).

It may be assumed that some species of shrews have difficulty in balancing energy requirements during this period. This can be gathered from the fact that about $34 \%$ of moulting $S$. araneus (Borow ski, 1968 ) and about $60 \%$ of $N$. fodiens (Table 4) have an interrupted moult in the spring. The spring moults are not interrupted in $S$. minutus, or at least no such case was found among the 43 individuals examined (cf. Table 8). Interrupted spring moults were also observed in Blarina brevicauda (W illiams, 1962), a relatively large representative of Soricinae (body weight 15 to $30 \mathrm{~g}$ ). If therefore interrupted moult is to be considered as a phenomenon deviating from the normal, or as poorer physiological capacity, then the following relation becomes clear: in shrews with higher metabolic rate the moult takes place more efficiently, or conversely that a higher metabolic rate is essential for an efficient moult.

Spring moult II ends in S. araneus at the beginning of June (B o r o w$\mathrm{sk} \mathrm{i}, 1968$ ) and the spring growth of overwintered adults also ends during this period (cf. Pucek, 1970). Although reproduction still continues up to the end of summer, there are scattered senile moults, but these processes do not cause a rise in metabolic rate, on the contrary it decreases markedly (G ę b c zyński, 1965).

The above discussion is of course open to question. A more detailed analysis of the relation between moult and metabolic rate, in particular evaluation of the energy expenditure due to moulting, would require further detailed physiological studies.

Acknowledgments: I should like to express my gratitude to Professor dr. Z. P uc e $\mathrm{k}$ for his critical and constructive comments when I consulted him on many occasions during the preparation and writing of this study, and to all my scientific colleagues, particularly A. and S. Fe dy k, M. Sc., for the critical review of the first draft of this paper. I am greatly indebted to E. W o lk, M. Sc. for her assistance in direct observations of changes in coat in the laboratory animals at the end of 1966 and beginning of 1967, and to G. K. B a g got t, B. Sc. (Durham University) for reading of the manuscript and valuable corrections of the text.

\section{REFERENCES}

1. Borowski S., 1952: Sezonowe zmiany uwłosienia u Soricidae. Annls Univ. M. Curie-Skłodowska, Sect. C 7, 2: 65-117, Lublin.

2. Borowski S., 1959: Variations in density of coat during the life cycle of Sorex araneu araneus L. Acta theriol., 2, 14: 286-289.

3. Borowski S., 1963: Old-age moult in the Common shrew, Sorex araneus Lin n a e s, 1758. Acta theriol., 7, 19: 374-375. 
4. B orowski S., 1964: Moult of shrews (Sorex L.) under laboratory conditions. Acta theriol., 8, 8: 125-135.

5. Borowski S., 1968: On the moult in the Common shrew. Acta theriol., 13, 30: $483-498$.

6. Brauckhoff H., 1958: Physik des Haares. Beiträge zur Haut-, Haar und Fellkunde, 7: 1-127. Verl. Paul Schöps, Koblenz am Rhein.

7. Cerevitinov B. F., 1958: Topografičeskije osobennosti wolosianogo pokrova pušnych zverej. Tr. Vses. N.-issl. In-ta Životn. Syria i Pušniny, 17: 256-307.

8. Choate J. R., 1970: Systematics and zoogeography of Middle American Shrews of the genus Cryptotis. Univ. Kansas Public., Mus. Nat. Hist., 19, 3: $195-317$

9. Crowcroft P., 1955: Remarks on the pelage of the Common shrews (Sorex araneus L.). Proc. Zool. Soc. Lond., 125, 2: 309-315.

10. Crof croft P., 1956: On the life span of the Common shrew (Sorex araneus L.). Proc. Zool. Soc. London, 127, 2: 285-292.

11. Crofcroft P., 1957: The life of the shrew. M. Reinhard: 1-166, London.

12. Dehnel A., 1949: Studies on the genus Sorex L. Annls Univ. M. Curie-Skłodowska, Sect. C 4, 2: 17-102. Lublin.

13. Dehnel A., 1950: Studies on the genus Neomys Ka u p. Annls Univ. M. Curie-Skłodowska, Sect. C 5, 1: 1-63. Lublin.

14. Dolgov V. A., 1966: Vidy palearktičeskich zemlerojek roda Sorex i ich individualnaja i populacjonnaja izmenčivost'. Univ. M. V. Lomonosova: 3-19. Moskva.

15. Findley J. S. \& Jones J. K., 1956: Moult of the Short-tailed shrew Blarina brevicauda. Am. Midl. Nat., 1: 246-249.

16. Gębczyńska Z. \& Gębczyński M., 1965: Oxygen consumption in two species of the Water-shrews. Acta theriol., 10, 13: 209-214.

17. Gębczyński M., 1965: Seasonal changes in the metabolism and activity of Sorex araneus Linnae us, 1758. Acta theriol., 10, 22: 303-331.

18. Gębczyński M., 1971: The rate of metabolism of the Lesser shrew. Acta theriol., 16, 20: 329-339.

19. Gębczyński M. \& Olszewski J., 1963: Katathermometric measurements of insulating properties of the fur in small mammals. Acta theriol., 7, 19: $369-371$.

20. Hamilton W. J., 1940: The moult of Blarina brevicauda. J. Mammal., 21, 4: $457-458$.

21. Hamilton W. J., 1944: The biology of the Short-tailed shrew, Cryptotis parva. J. Mammal., 25, 1: 1-7.

22. Ivanter E. V. \& Ivanter T. V., 1968: Obyknovennaja burozubka v zapovednike „Kivač”. Tr. Zap. „Kivač”, 1: 116-135.

23. J a cks on H. H. T., 1928: A taxonomic review of the American longtailed shrews (genera Sorex and Microsorex). North Amer. Fauna, 51: 1-233 (I-VI), Washington.

24. J u di n B. S., 1964: Geografičeskoje raspredelenije i vnutrividovaja taksonomija krošečnoj burozubki $\mathrm{v}$ zapadnoj Sibiri. Acta theriol., 8, 10: 167-179.

25. Kahmann H. \& Rössner F. X., 1956: Die Natur der Färbungsvielesteltigkeit der huterseite bei der Wasserspitzmaus (Neomys). Naturwissen., 43, 2: 46. Heidelber. 
26. Kryltzov A. I., 1964: Moult topography of Microtinae other Rodent and Lagomorphs. Z. Säugetierk., 29: 1-17.

27. Lehman E., 1962: Farb-Phasen und Farb-,,Rassen”. Säugetierk. Mitt., 10, 4: $168-173$.

28. Lehman E., 1966: Anpassung und "Lokalkolorit" bei den Soriciden Zweier linksrheinischer Moore. Säugetierk. Mitt., 14, 2: 127-133.

29. Ling J. K., 1970: Pelage and molting in wild mammals with special reference to aquatic forms. Quart. Rev. Biol., 45, 1: 16-54.

30. Michielsen N. C., 1966: Intraspecific and interspecific competition in the shrews Sorex araneus L. and Sorex minutus L. Arch. Neerl. Zool., 17, 1: 73-174.

31. Mohn M. P., 1958: The effects of different hormonal states on the growth of hair in rats. [In: "The biology of hair growth", Eds W. Montagna \& A. E 11 i s]: 335-398. Academic Press, New York.

32. Negus N. C., 1958: Pelage stages in the cottontail rabbit. J. Mammal., 39: 246-252.

33. Niethammer J., 1956: Das Gewicht der Waldspitzmaus, Sorex araneus Li nne im Jahreslauf. Säugetierk. Mitt., 4, 4: 160-165.

34. Ostwald W., 1939: Die kleine Farbmesstafel. Ausg. c., »Musterschmidt« Wiss. Verl. Göttingen: 1-10. Frankfurt-Berlin.

35. Ott J. \& Olert J., 1970: Färbungsunterschiede zwischen Sorex araneus Linnaeus, 1758 und Sorex gemellus Ot t, 1968 (Mammalia, Insectivora). Rev. Suisse Zool., 77: 283-291.

36. Popov V. A., 1960: Mlekopitajuščije Volžsko-Kamskogo kraja (nasekomojadnyje, rukokrylyje, gryzuny). AN. SSSR., Kazan. Fil.: 1-466.

37. Pucek Z., 1959: Some biological aspects of the sex-ratio in the Common shrew (Sorex araneus araneus L.). Acta theriol., 3, 4: 43-73.

38. Pucek 7., 1970: Seasonal and age changes in shrews as an adaptative process. Symp. Zool. Soc., London, 26: 189-207.

39. S okolov W. E., 1968: Strojenije i adaptivnyje osobennosti koži nasekomojadnych. Vestn. Mosk. In-ta, 3: 20-31.

40. Speth R. L., 1969: Patterns and sequences of molt in the Great Basin Packed Mouse, Perognatus parvus M e r. J. Mammal., 50, 2: 284-290.

41. Stein G. H. W., 1954: Materialen zum Haarwechsel deutschen Insectivoren. Mitt. Zool. Mus. Berlin, 30, 1: 12-34.

42. Strog on ov S. U., 1957: Zveri Sibiri. Nasekomojadnyje. Zap.-Sib. Fil. AN. SSSR: $1-267$.

43. Ś va r c S. S., 1955: Biologija zemlerojek lesostepnogo Zauralia. Zool. Zurn., 34, 4: $915-927$.

44. Tarkowski A. K., 1957: Badania nad rozrodem i śmiertelnością zarodkową u ryjówki aksamitnej (Sorex araneus L.). Cz. II. Rozród w warunkach naturalnych. Annls Univ. M. Curie-Skłodowska, Sect. C 10, 8: 177-244.

45. Toldt K., 1935: Aufbau und natürliche Färbung des Haarkleides der Wildsäugetiere. Deut. Gesell. für Kleintier- u. Pelztierzucht G. m. b. H. \& Co.: 1-291. Leipzig.

46. Wilcke G., 1938: Freilands- und Gefangenschaftsbeobachtungen an Sorex araneus L. Z. Säugetierk., 12: $332-335$.

47. Willi a m s M. W., 1962: Moult in Blarina brevicauda. J. Mammal., 43, 3: 423 -424 . 
48. $\mathrm{Z}$ i mmerman $\mathrm{n}$ K., 1952: Vergleichende Farbtabellen. Verl. Paul Schops: 1 -47. Frankfurt/Main.

Accepted, March 15, 1973.

Mammals Research Institute, Polish Academy of Sciences, 17-230 Białowieża, Poland.

Stanisław BOROWSKI

\section{ZMIANY UWEOSIENIA I UBARWIENIA U PRZEDSTAWICIELI RODZAJU SOREX L. I NEOMYS KA UP.}

\section{Streszczenie}

Przedstawiono wyniki badań nad zmianami uwłosienia u czterech gatunków Soricidae i porównano je $\mathrm{z}$ wcześniejszymi danymi dla ryjówki aksamitnej (B or ow ski, 1968). Pozwoliło to na ustalenie ogólnych prawidłowości przebiegu procesów linienia krajowych przedstawicieli rodzajów Sorex L. i Neomys Ka u p.

Materiał do badań stanowiły 1123 okazy Sorex minutus minutus Linnaeus, 1766, 115 okazów S. caecutiens karpińskii Dehnel 1949, 1430 okazów Neomys fodiens fodiens (Pennant 1771) i 234 okazy $N$. anomalus milleri (Mot taz 1907) - lowione w Białowieskim Parku Narodowym w latach 1946-1968.

Ubarwienie sierści na grzbiecie u badanych gatunków jest ogólnie brązowoczarne. Barwa sierści na bokach u rodzajów Sorex jest nieco jaśniejsza od barw grzbietu, a u rodzaju Neomys - taka sama. Barwa sierści na brzuchu u wszystkich zwierząt jest jaśniejsza od barwy grzbietu i boków, ogólnie - popielata, a najbardziej zmienna jest u $N$. fodiens (Table 2, 5, 7, 9).

Duża zmienność ubarwienia w obrębie populacji białowieskich Soricidae przemawia za tym, że nie należałoby opierać systematyki podgatunkowej tylko na barwie futerka.

Długość sierści jest wprost proporcjonalna do wielkości ciała zwierząt (Tabela 3), a odwrotnie proporcjonalna $\mathrm{w}$ przeliczeniu na $1 \mathrm{~g}$ masy osobnika (Tabela 11).

U przedstawicieli rodzaju Sorex wyróżniono 4 kategorie linek: jesienną, dwie wiosenne i starczą (Ryc. $1 \mathrm{D}-\mathrm{L}$ ). U obu gatunków rzęsorków stwierdzono ponadto linkę młodocianą (juvenilną) - ryc. $1 \mathrm{~A}-\mathrm{C}$.

U wszystkich badanych gatunków oraz we wszystkich linkach sezonowych (kategoriach) wyróżniono 3 typy linek: całkowitą, falową i dyfuzyjną (Fot. $1-3,5,6$ ).

Stwierdzono zgodność przebiegu poszczególnych linek u badanych przedstawicieli Soricidae. I tak: linka juvenilna ma przebieg grzbietowo-brzuszny (ventrad), linka jesienna zaczyna się na krzyżu i przebiega grzbietem do przodu, potem schodzi na brzuch w okolicy ingwinalnej i dolem posuwa się do przodu (cephalo-ventrad), linka wiosenna I zaczyna się w okolicy ingwinalnej, a kończy się na grzbiecie ciała (cephalo-dorsad), linka wiosenna II ma przebieg całkowicie odwrotny (caudo-ventrad). Linka starcza (diffuse) ma przebieg nieregularny (Tabela 1).

Istnieje znaczna synchronizacja przebiegu linek u poszczególnych gatunków ryjówkowatych (Ryc. 7), przy czym u rzęsorków obserwuje się opóźnienie zmiany uwłosienia podczas linki wiosennej II w stosunku do ryjówek. 


\section{EXPLANATION OF PLATES}

Plate IV

Photo 1. Successive stages in total juvenile moult in $N$. fodiens.

Photo 2. Successive stages in total autumn moult in $N$. fodiens.

\section{Plate V.}

Photo 3. Two types of spring moult I in $N$. fodiens.

$$
\text { a - wave, b - total. }
$$

Photo 4. Interrupted spring moult II in $N$. fodiens.

a - from hair side, $\mathrm{b}$ - the same skins from the underside. The distinct line of demarcation between long (spring) and short (summer) hair (a) and absence of pigmentation of the skin (b) can be seen.

Plate VI.

Photo 5. Senile moult in $N$. fodiens.

a - diffusive type, $\mathrm{b}$ - over larger areas of the body (almost total).

Photo 6. Autumn moult in S. minutus.

a - total, extending over the back of the body, b - final stage - the ventral side moults, while the back has the winter hair, c - wave-type autumn moult.

Photo 7. Spring moult II (interrupted) in S. caecutiens.

Long spring hair can be seen round the lateral glands and in the inguinal area. No dark pigmentation of the skin. 


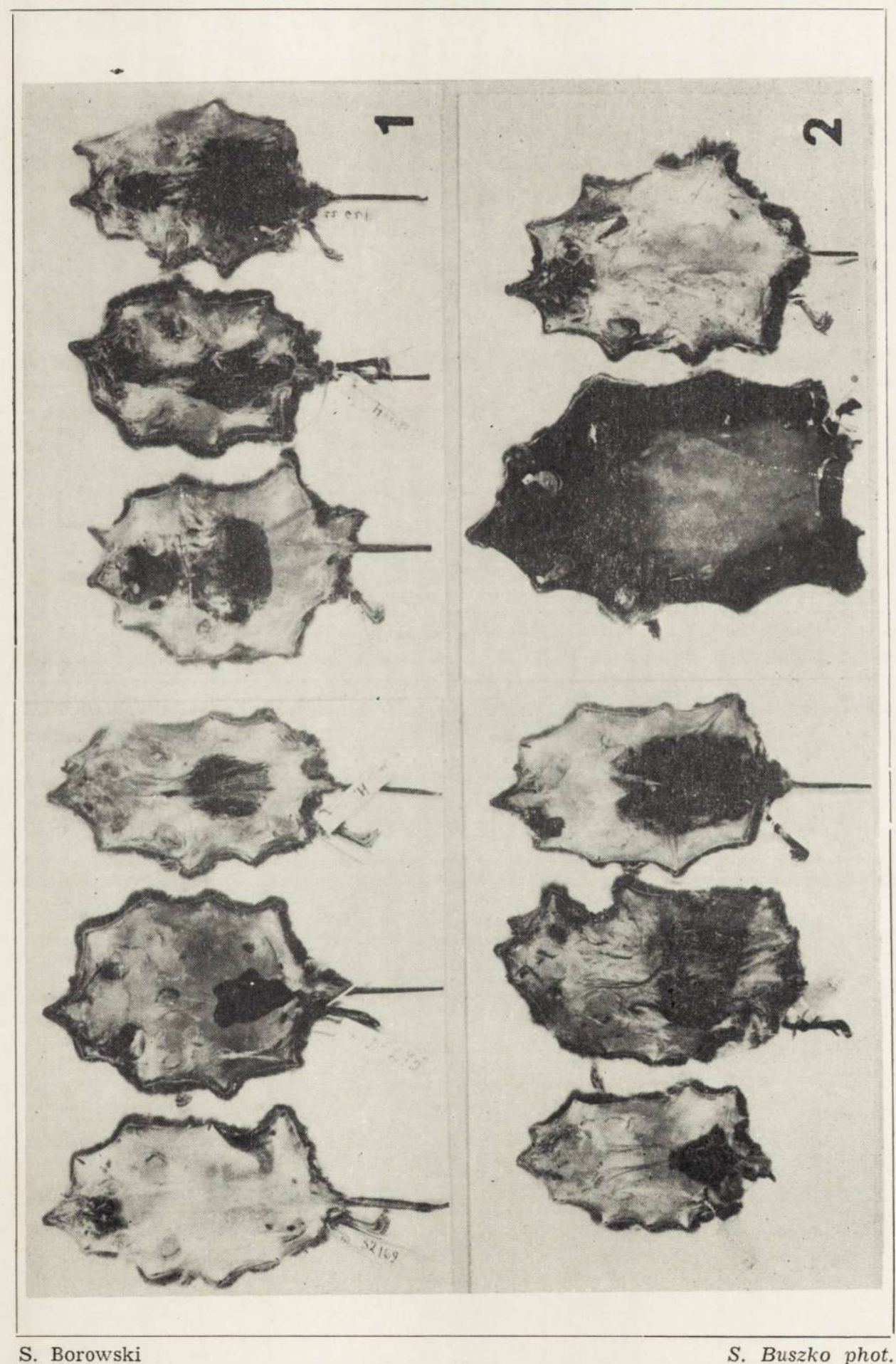




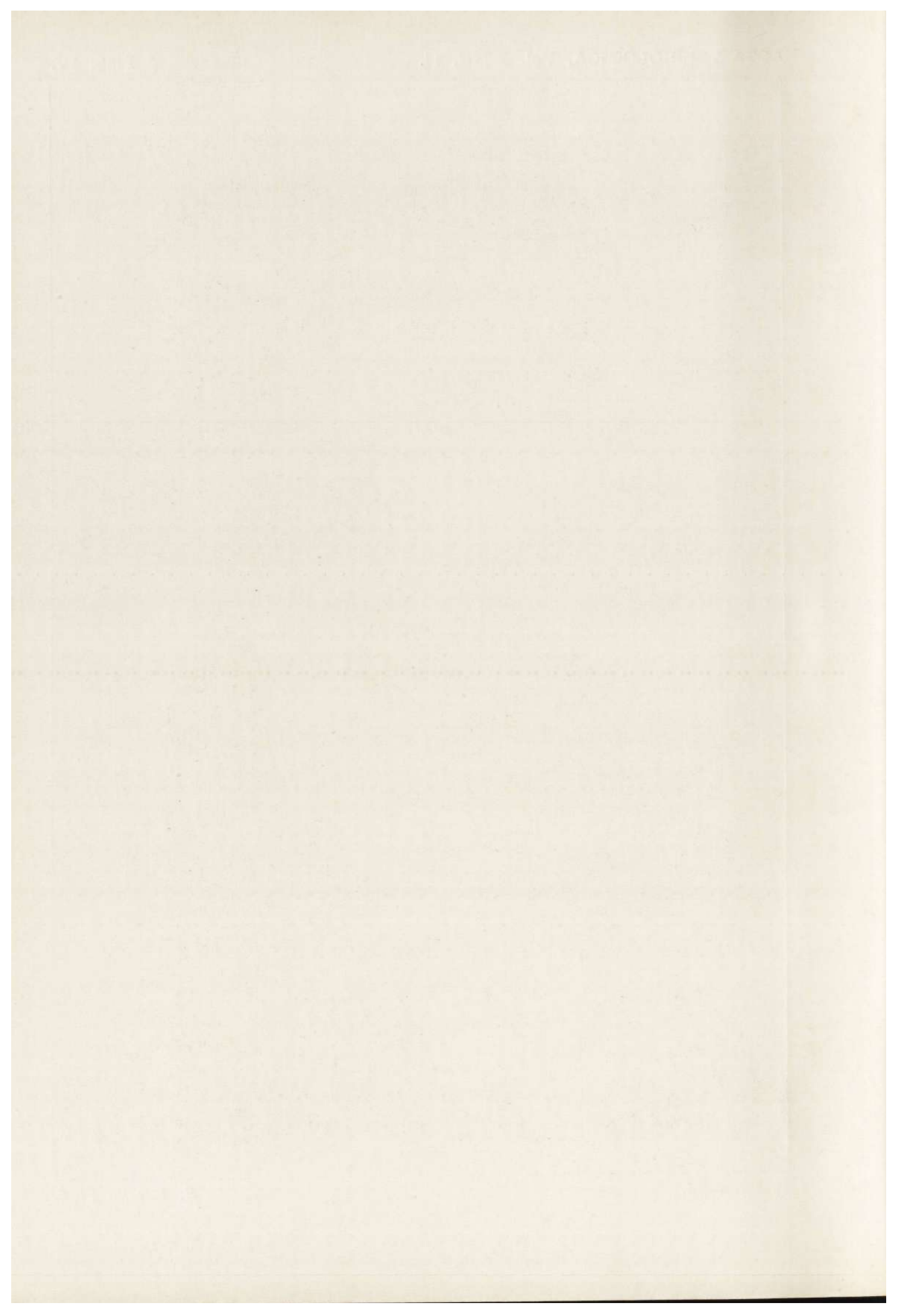


ACTA THERIOLOGICA, Vol. XVIII, 14.

Plate V.

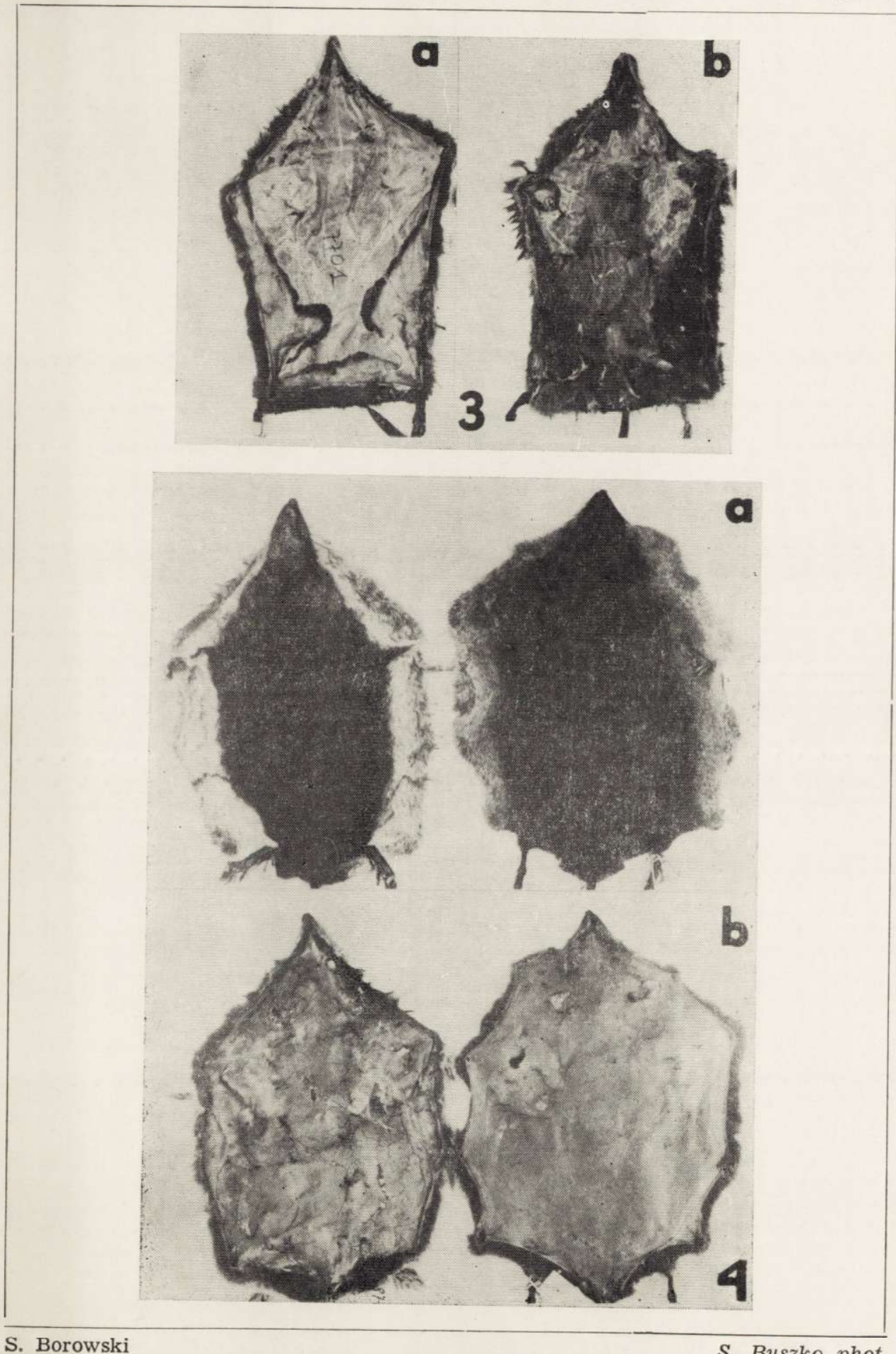

S. Borowski

S. Buszko phot. 


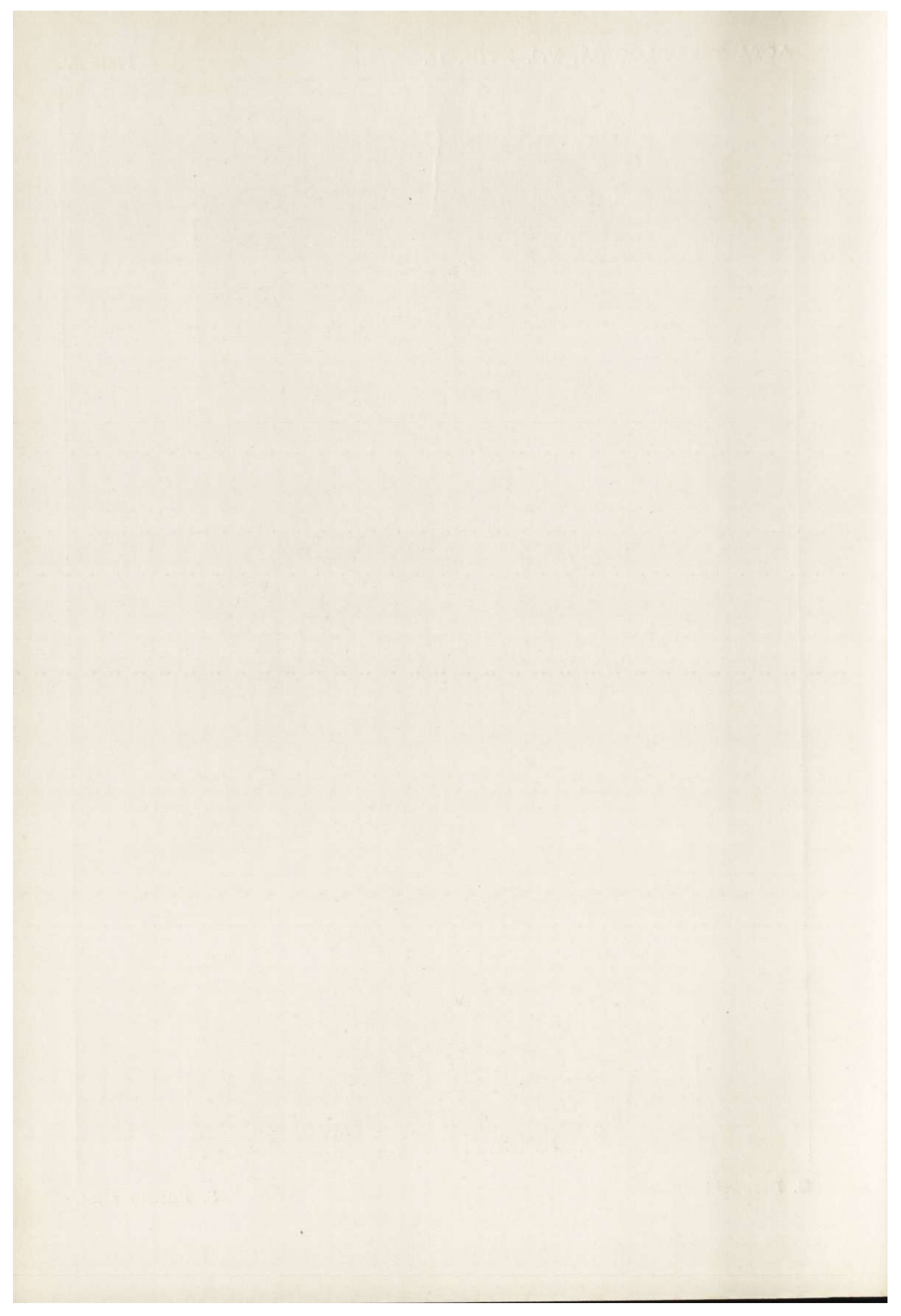


ACTA THERIOLOGICA, Vol. XVIII, 14.

Plate VI.

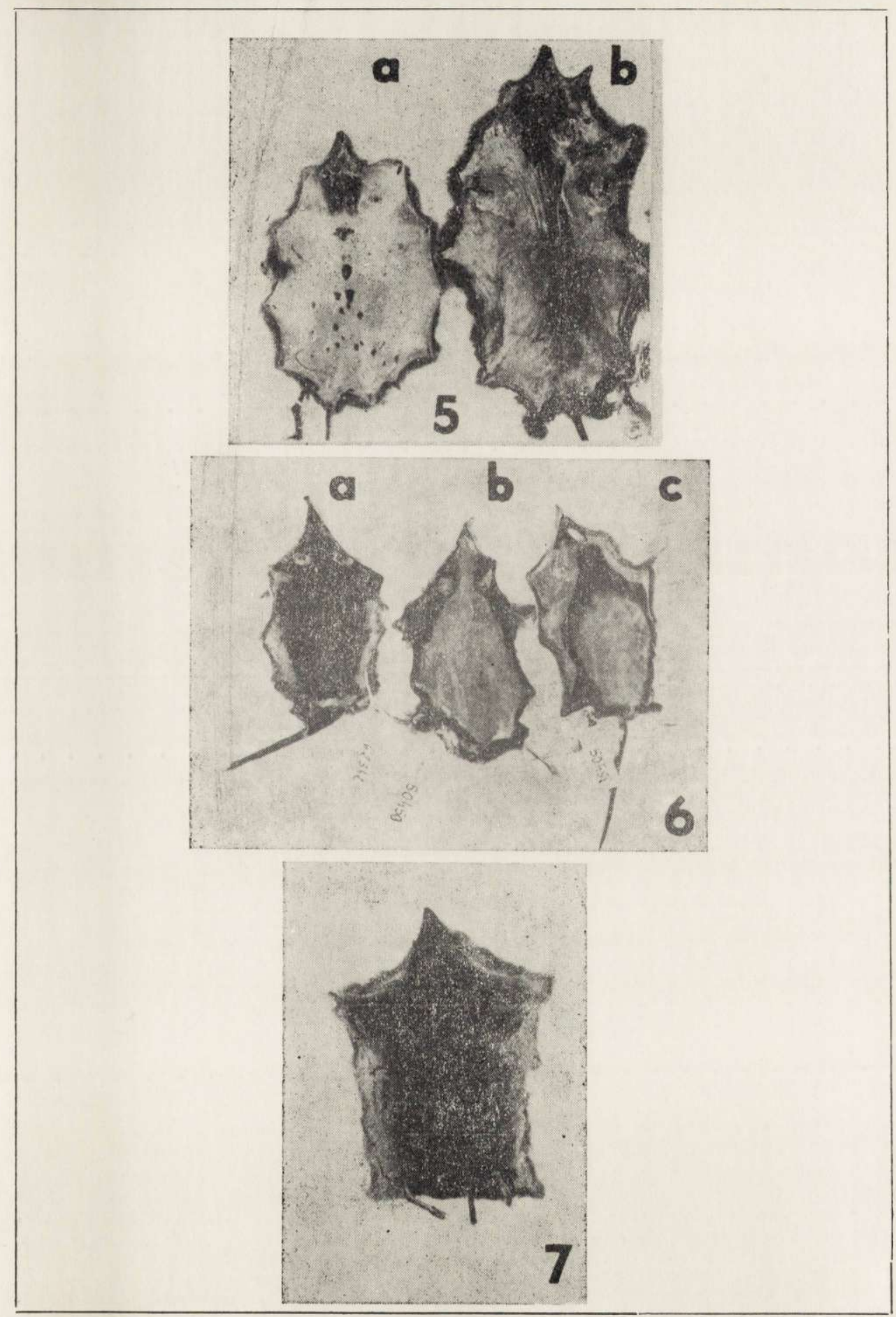

S. Borowski

S. Buszko phot. 


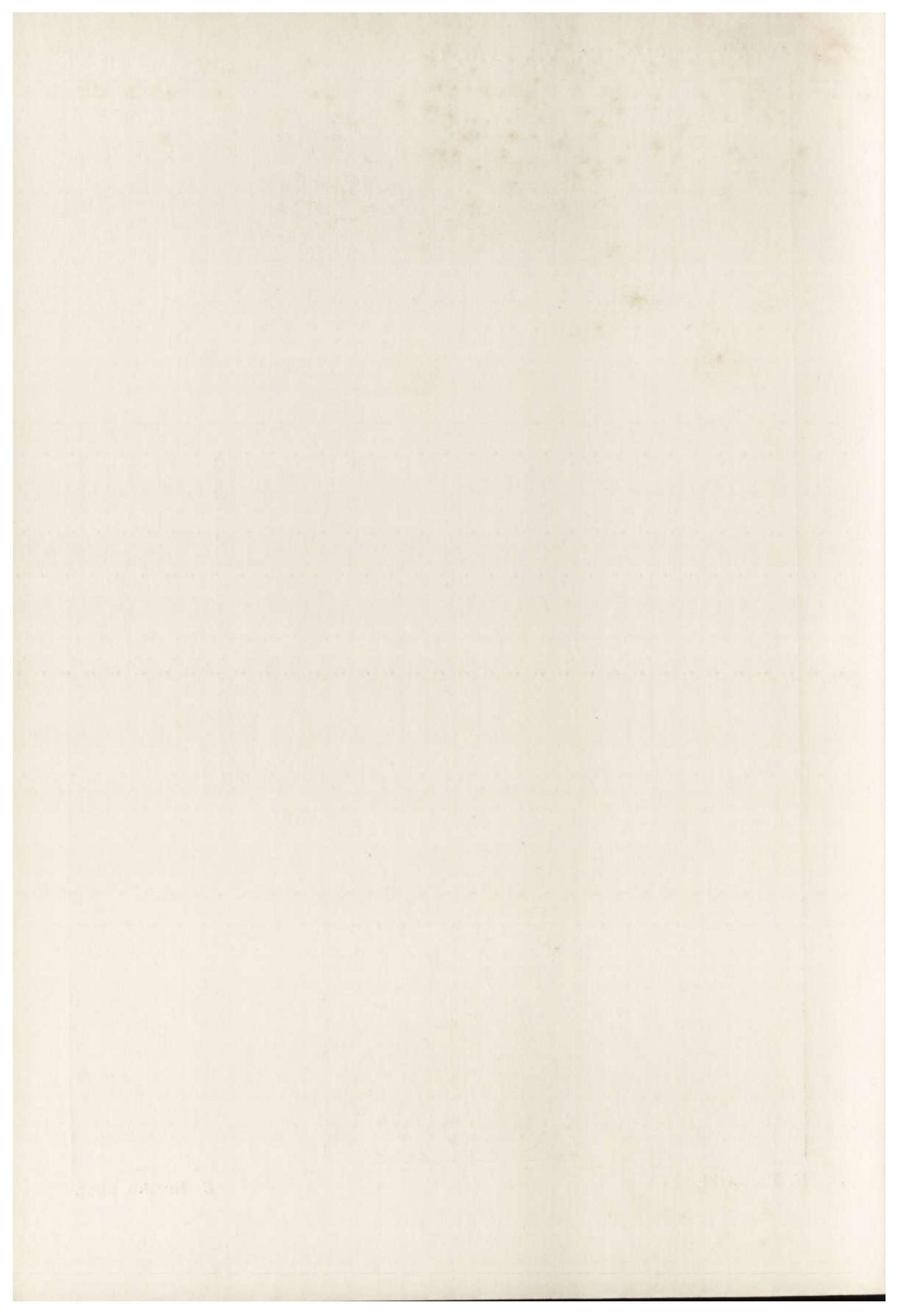

